\title{
Current Status and Review of Waste-to-Biogas Conversion for Selected European Countries and Worldwide
}

\author{
Matevž Zupančič ${ }^{1}\left(\mathbb{D}\right.$, Valerija Možic ${ }^{1}$, Matic Može ${ }^{1, * \mathbb{D}}$, Franc Cimerman ${ }^{2}$ and Iztok Golobič $^{1}$ \\ 1 Faculty of Mechanical Engineering, University of Ljubljana, Aškerčeva 6, 1000 Ljubljana, Slovenia; \\ matevz.zupancic@fs.uni-lj.si (M.Z.); valerija.mozic@gmail.com (V.M.); iztok.golobic@fs.uni-lj.si (I.G.) \\ 2 Plinovodi d.o.o., Cesta Ljubljanske brigade 11b, p.p. 3720, 1001 Ljubljana, Slovenia; \\ franc.cimerman@plinovodi.si \\ * Correspondence: matic.moze@fs.uni-lj.si; Tel.: +386-1-4711-309
}

Citation: Zupančič, M.; Možic, V.; Može, M.; Cimerman, F.; Golobič, I. Current Status and Review of Waste-to-Biogas Conversion for Selected European Countries and Worldwide. Sustainability 2022, 14, 1823. https://doi.org/10.3390/ su14031823

Academic Editor: Antonio Zuorro

Received: 14 January 2022

Accepted: 2 February 2022

Published: 5 February 2022

Publisher's Note: MDPI stays neutral with regard to jurisdictional claims in published maps and institutional affiliations.

Copyright: (c) 2022 by the authors. Licensee MDPI, Basel, Switzerland. This article is an open access article distributed under the terms and conditions of the Creative Commons Attribution (CC BY) license (https:/ / creativecommons.org/licenses/by/ $4.0 /)$.

\begin{abstract}
Growing world population and increasing population density are leading to increasing waste production with biological waste amounting to several billion tonnes annually. Together with the increasing need for renewable energy sources, waste-to-biogas conversion as a prime example of waste-to-energy technology represents a facile way of solving two problems simultaneously. This review aims to address the recent progress in the field of waste-to-biogas technology, which is lately facing intensive research and development, and present the current status of this waste treatment method both in technological and legislative terms. The first part provides an overview of waste and waste management issues. This is followed by a detailed description of applicable waste-to-energy (WtE) technologies and their current implementation in selected European countries. Moreover, national energy and climate plans (NECPs) of selected EU Member States are reviewed and compared with a focus on implementation of $\mathrm{WtE}$ technologies. In a further section, biogas production from waste around the world is reviewed and compared country wise. Finally, an outlook into the future of $\mathrm{WtE}$ technologies is provided alongside the conclusions based upon the reviewed data.
\end{abstract}

Keywords: waste; biogas; methanation; waste-to-biogas; waste-to-energy; gas separation

\section{Introduction}

Due to the growing world population, municipal and household waste generation is increasing as well. In densely populated areas and in environments where tourism is particularly well-developed, the re is an accumulation of food waste. Similarly, agriculture is faced with difficulties, such as large volumes of agricultural residues and biodegradable waste, which are not suitable for human consumption, and livestock waste. The annual amount of all waste produced in the world is estimated to be between 7 and 9 billion tonnes, of which more than 2 billion tonnes represent the municipal solid waste (MSW) [1,2], the production of which is projected to reach 3.4 billion tonnes by 2050. Almost one third of all food produced for human consumption is lost or discarded, amounting to 1.3 billion tonnes annually [3]. The amount of solid municipal waste among European OECD member countries represented around 284 million tonnes in 2018, and the amount of waste among all OECD member countries has increased by $4.6 \%$ in 16 years, from around 652 million tonnes in 2002 to more than 682 million tonnes in 2018 [4]. Because waste management represents one of the core issues of modern society, many efforts are devoted to developing processes to reduce waste accumulation in landfills, including waste separation in developed countries, which makes waste disposal and recycling easier and cheaper. Furthermore, biological waste is mostly compostable and can be naturally decomposed and burned. Additionally, waste sludge is generated as a by-product of municipal and industrial wastewater treatment and needs to be disposed of. However, despite the effective reduction in waste that ends up at landfills, the mentioned conventional processes can have several adverse environmental effects including greenhouse gas emissions as well as groundwater, 
soil and air pollution. One of the environmentally friendly waste management processes is waste-to-gas ( $\mathrm{WtG}$ ) technology, where biodegradable waste is processed into biogas through the process of anaerobic digestion. In addition to the efficient use of resources and the reduction in $\mathrm{CO}_{2}$ emissions, biogas plants also have a favourable economic impact, and they produce environmentally friendly energy. The general acceptance of biogas plants by nearby residents is positive, but there are prejudices that affect their general acceptance, such as unpleasant odours in the vicinity of the biogas plant, traffic and noise, hazards for nature and competitions for food production [5].

In general, raw materials for biogas plants can be classified into the following six groups:

- Animal waste including animal manure, urine and wastewater from washing stables are all ideal raw materials for anaerobic digestion. The quantity of animal waste depends on the type of animal, its weight, physiological condition, feed composition and feeding methods [6]. However, animal manure has certain disadvantages, namely, it usually comes in large quantities and consequently has low dry-matter content, which results in low biogas yield per unit of processed raw material and high costs of raw material or digestate transportation. Additionally, animal waste may contain heavy metals and antibiotics, which have unfavourable effects on the process of anaerobic digestion or on the reuse of digestate [6,7]. The moisture content and the content of organic matter in the material significantly affect the quality of the final product, as they stimulate the growth of microorganisms [8]. However, it has been recently shown that the implementation of freeze concentration technology as an alternative way to recover nutrients from agro-industrial waste digestate makes it easier to transport animal waste due to volume reduction [9]. Traditional methods of drying materials with high moisture are cost intensive and have negative environmental effects. On the other hand, bio-drying is mostly suitable for municipal solid waste, waste from the pulp and paper industry, sewage sludge and green waste. In this auto-thermal process, waste is dried as a result of the thermal energy released during aerobic decomposition of the biodegradable fraction, while intensive aeration causes moisture removal [10].

- Garden and field waste represents another possible raw material for biogas production, boasting a high dry matter fraction, high yield of biogas per unit of fresh weight, low transportation costs and low production of liquid digestate. On the other hand, long retention times are needed for their digestion due to high levels of cellulose, hemicellulose and lignin. Furthermore, the carbon-to-nitrogen $(C / N)$ ratio is high (usually above 50), which is unfavourable for the normal growth of microorganisms, and also increases the biogas plant or anaerobic digestion start-up delay [6]. Admixing additives to waste has been shown to increase the effectiveness of biostabilisation, resulting in shorter times and lower energy consumption to achieve the same results, namely, at least $7.5 \%$ of added digestate reduces the $\mathrm{C} / \mathrm{N}$ ratio and consequently speeds up the process [11]. Residues in digestors are also difficult to remove when garden and field waste are processed $[12,13]$. Within this type of waste, maize has the highest biogas yield, followed by wheat and rice $[6,14]$.

- Industrial organic waste, mostly consisting of food and beverage waste as well as waste from sugar, starch and fruit processing, is produced in large quantities. Waste with a high content of hydrocarbons, fats and proteins is the most suitable for biodigestion [15-18].

- Municipal waste is solid waste generated in people's daily lives and it includes household waste, commercial waste and waste from cleaning. Organic waste is comprised of fractions of household waste, garden waste and similar organic waste. Impurities such as metal, glass, plastic and sand may seriously affect the operation of a biogas plant and must therefore be removed beforehand $[6,14,19-21]$. The aforementioned bio-drying process decreases the number of some pathogens or completely eliminates them, while for Escherichia coli (E. Coli), abundantly present in municipal solid waste, this effect is not entirely satisfactory. The biggest problem with drug resistant $E$. Coli is 
that it can spread outside the landfill area and may adversely affect people working in waste storage and processing [22].

- Food waste includes kitchen waste, food waste from restaurants, hotels, canteens, waste from the processing of fruit, vegetables, fat, flour, etc. In comparison with other types of waste, food waste has a high content of fat and salt as well as impurities, such as bones, utensils and other kitchenware parts, which may damage pumps, pipes and other equipment and must therefore be removed during the pretreatment phase [23-25]. As an example, large quantities of hot trub generated in breweries during beer production end up in landfills. Hot trub presents a valuable waste source for WtE processes but also contains E. Coli. Recent research has shown that hot trub can also be used in medicine as a sedative or in cosmetology, which could consequently reduce the amount deposited into landfills [26]. Still, the worst solution for disposing of sediments from breweries is to direct them into the municipal sewage system, which increases the costs of wastewater treatment and is irrational from an ecological and economic point of view [27].

- Municipal sludge includes various types of sludge and waste produced by municipal wastewater treatment plants and has a high water content, large volume and is unstable. Sludge from primary and secondary sedimentation processes is rich in organic matter, the digestion of which is simple and suitable for anaerobic treatment and has a similar potential for biogas production as animal manure.

While the primary objective is the reduction in both the amount and the rapid growth of food waste and municipal solid waste worldwide, current methods of waste management further burden the environment, making the production of biogas through the process of anaerobic digestion the most attractive alternative solution, which at the same time contributes towards the decarbonisation of the society. The goal is to process as much waste as possible, which would lead to a higher share of renewable gases in the energy supply. By purifying biogas and upgrading it to biomethane, investing in existing technologies could enable the injection of biomethane into national gas networks and promote the use of biomethane as a fuel for vehicles, consequently reducing the greenhouse gas emissions. One of the long-term goals of the Paris Agreement [28] is to limit the global average temperature rise to $2{ }^{\circ} \mathrm{C}$, with a desire to achieve $1.5^{\circ} \mathrm{C}$, which would greatly reduce the risks and impacts of climate change. The EU's initial nationally determined contribution under the Paris Agreement was the commitment to reduce greenhouse gas emissions by at least $40 \%$ by 2030 compared to 1990 . Furthermore, one of the key achievements of COP26 [29] was a pledge to halt and reverse deforestation by 2030, a pledge through which more than 100 countries agreed to cut emissions of methane by 2030 and a signed Glasgow Declaration on Zero-Emission Cars and Vans to end the sale of internal combustion engines by 2040 worldwide.

\subsection{Waste Management Issues}

Management of different types of waste represents a big challenge, mainly due to their heterogeneous nature. Waste management issues are not only associated with developed parts of the world with the high population density generating large amounts of waste. Furthermore, waste management problems are not only linked to highly developed tourist countries with a surplus of food, mainly from restaurants. Waste management is also an important issue in rural areas and developing countries, mainly due to both the low socio-economic status of the majority of the population and also the lack of awareness, technology and the absence of the need for proper waste management.

\subsection{Environmental Issues}

Poor waste management can have a negative impact on the environment and can cause air pollution caused by gases generated during open combustion or released from landfills and during waste incineration. It may also lead to various health problems due to the increased spread of bacteria, flies and rodents in landfills, and it may also 
result in greenhouse gas emissions caused by methane and carbon dioxide emissions. Municipal solid-waste landfills can also cause groundwater contamination resulting from uncontrolled leachates [30-34].

A growing amount of food waste is accumulating on composts and landfills, resulting in increased greenhouse gas emissions, increased water consumption in agriculture and the use of unnecessary plastic for food packaging [35]. Waste generated in agriculture, particularly in intensive livestock farming, affects soil pollution, even though animal manure was considered a beneficial addition to soil in the past due to being rich in nutrients and organic matter and helping to maintain physical properties of soil, such as moisture retention and structure. Recurrent and excessive use of manure in soil has led to the accumulation of not only macronutrients, such as nitrogen, phosphorous and potassium, but also heavy metals, such as zinc and copper, resulting in a negative impact on the health of animals fed predominantly on pasture. Water pollution caused by livestock farming is associated with removal of minerals from the soil, whereas air pollution is caused by more than a hundred gaseous compounds, which are released into the atmosphere by means of ventilation systems and are formed in freshly deposited or stored excrement and urine through microbial reactions; most concerns in this field are, however, raised on the account of foul-smelling gases and ammonia [36].

The same impact on soil pollution as in intensive livestock farming is also encountered in the treatment of sewage sludge and sludge arising from wastewater processing, where the impact of negative effects may be immediate or delayed, depending mainly on a waste disposal method or waste management method $[7,14,19,37]$.

\subsection{Problems Related to Waste Management Methods}

The most important greenhouse gases resulting from human activity, such as electricity and heat production $(25 \%)$, agriculture, forestry and other land use (24\%), industry $(21 \%)$, transportation (14\%), buildings (6\%) and other energy $(10 \%)$, are $\mathrm{CO}_{2}, \mathrm{CH}_{4}, \mathrm{~N}_{2} \mathrm{O}$ and fluorinated gases [38]. Public landfills represent the simplest way to manage waste as they generate the lowest costs and do not require highly qualified personnel. While they have many negative impacts on and risks to human health, the y are still the most used solution for managing waste. This is despite landfills representing the least favourable option in the waste management hierarchy, because of landfill gases (caused by microbial decomposition of organic matter in anaerobic conditions) that have a major impact on atmospheric pollution. Landfill gases consist of $\mathrm{CH}_{4}, \mathrm{CO}_{2}$ and more than 200 non-methane volatile organic compounds [39]. Landfill emissions have the greatest impact on ozone depletion and climate change and also cause acidification, eutrophication and ecotoxicity. In such waste management, the re is a possibility of spontaneous ignition or explosion and the contamination of surface drainage during precipitation as well as soil and groundwater pollution may occur. If a landfill has an appropriate system of leachate treatment, the $\mathrm{n}$ the groundwater pollution is less intensive [40-42]. During the storage of polymeric materials obtained from organically degradable waste, spontaneous combustion can quickly occur due to aerobic decomposition of organic fractions, which, according to recent research, can be prevented by adding small doses of calcium oxide, effectively inactivating and eliminating most microorganisms [43].

Composting is one of the most important organic waste management practices that can be used to achieve soil and environmental sustainability. Compost has a minimal impact on some emissions, while a composting pit can help control the carbon footprint and limit the negative environmental effects of poorer waste disposal methods [44].

Waste incineration is not suitable for waste with a high moisture content and low calorific value as well as for chlorinated waste. Such waste management raises concern due to the release of toxic materials, which may have a negative impact on human health. Furthermore, such approach leads to even more greenhouse gas emissions. Moreover, low-power incineration plants have a low overall efficiency, while start-up capital and maintenance costs are high as highly qualified personnel are required for operation [40,42]. 


\subsection{Aim, Scope and Structure of the Review}

The aim of this review paper is to investigate the current situation in the field of waste-to-biogas both in Europe and worldwide. Previous reviews and research papers in this field mostly analyse technological progress [45-49], legislative limitations [50-53], case studies [54-61], impacts on efficiency [62-65], environmental impacts [66-70] and problems associated with public opinion [71-74]. A study of challenges including a proposed implementation framework for sustainable municipal organic waste management using biogas technology in Asian countries has also recently been conducted [75]. However, no existing review covers the interconnection between the national energy and climate plans of selected countries including the incorporation of waste-to-biogas technology and development of actual projects to reach these goals. To fill this gap, we compare the goals of individual Member States of the European Union on their path to decarbonisation and analyse existing plants for biogas production from waste as well as compare the current situation in the EU with the rest of the world.

The outline of main environmental issues regarding waste quantities and waste management technologies was provided in the introduction section. A more detailed description behind the waste-to-energy technology is provided in the second section. Special emphasis is put on biofuel types, the anaerobic digestion process and biogas utilisation, including biogas purification, upgrading and injection to national gas grids. Biogas injection, responsibilities and obligations of gas system operators and biogas producers are compared among different EU Member States. In the third section, selected countries are further compared through their National Energy and Climate Plans, where a critical analysis of projected biogas production and utilisation is also provided. Finally, existing biogas production projects, infrastructure and capabilities in the EU are compared to the situation worldwide. We specifically analysed the number of biogas projects and current biogas upgrading possibilities with the existing infrastructure. The main findings and conclusions, including an outlook, are summarised in the final section.

\section{Waste-to-Energy (WtE)}

Waste treatment is any physical, the rmal, chemical or biological process within the framework of waste recovery or waste disposal operations in accordance with a wastegoverning regulation, including waste sorting, which changes the properties of waste in order to reduce its volume, hazardous properties or the content of biodegradable substances to facilitate waste handling or to increase the possibilities for waste recovery [76]. The production of fuel from waste can take place either by thermal decomposition (gasification, pyrolysis and hydrolysis) or by biological processes (anaerobic digestion, fermentation). Research to date has found that, from an economic point of view, it makes the most sense to incinerate mixed waste, gasify parts of the fuel obtained from the waste and use organic waste as a raw material for anaerobic digestion [77]. Waste management remains an important subject. The goals of all WtE plants are hygienisation, volume reduction, environmental protection, mineralisation and immobilisation of hazardous substances, resource conservation, affordable costs and public acceptance. In developed countries, MSW energy accounts for $5 \%$ of the total energy demand. Efficient use of such energy can reduce the need for fossil fuels [78]. In European countries, about $560 \mathrm{~kg}$ of solid municipal waste is generated annually per capita, while in Asian countries, this amount ranges from 73 to $821 \mathrm{~kg}$. In all cases, the amount of annually generated waste per capita is constantly increasing [17]. Among the previously mentioned waste, between 25 and $80 \%$ is biodegradable. Given these figures, it is not surprising that biowaste management has become an important biotechnology and engineering sector not only in developed but also in developing countries. The origin of organic waste is very diverse. In addition to industrial and solid municipal waste, agricultural waste also significantly contributes to the total amount of waste. Biowaste treatment processes are based on the conversion of organic matter by means of chemical reactions through microorganisms, which play a key role in the digestion and conversion of organic matter and are responsible for the 
functioning of the nutrient cycle in ecosystems. Microbiological groups in organic waste are very diverse and are dynamically (and often also metabolically) closely bound to one another. By being familiar with the optimal physiological and environmental needs of microorganisms involved in the processing of organic waste, bioengineers can adapt process conditions in order to create ideal work conditions for microbes in integrated plants. However, the adaptation of environmental factors may lead to an emergence of undesirable groups of microorganisms or some adverse reactions; therefore, knowledge of microbial communities and their interactions is crucial for a successful treatment of the organic fraction of waste $[17,18,79]$.

\subsection{Biofuels}

Plant-based biofuels are a potential substitute for fossil fuels, and a smart choice of cultivation technology ensures the sustainable production of biofuels [80]. They have been developed as an alternative energy source to reduce greenhouse gas emissions and combat global warming. Biofuels are classified into the first, second, third and fourth generation, and what all generations have in common is that they want to meet global energy demand while reducing environmental impacts. The first generation has the highest biofuel production and energy efficiency but is less efficient in achieving its greenhouse gas reduction target [81] and cannot replace fossil fuels due to competition with food needs, as it uses edible biomass (sugar beet, sugar beet, wheat, maize) [82]. The second generation, unlike the first, uses inedible biomass (wood, straw, grass, waste) for production, but there are still limitations on cost-effectiveness in increasing production to a commercially viable level [83]. The third generation shows the lowest net greenhouse gas emissions, but the energy required to process the third-generation biofuels is higher, making it less environmentally friendly. Third and fourth generation raw materials represent a potential sustainable source for future biofuel production [81]. These two generations are more promising choices as they do not create such competition between food and fuels [82]. The third generation of biofuels uses microorganisms (macroalgae, microalgae) as a feedstock, and the fourth generation focuses on the genetic modification of these microorganisms (pyrolysis, engineered gasification of algae) [82].

Many ethical issues arise in connection with the deliberate cultivation of plants for the production of biofuels. One of these is whether intentionally growing food for the purpose of producing biofuels is appropriate, given the hunger crisis in some parts of the world. Plant-based fuel production has sparked major public controversy, particularly in the US in 2008, when rising world food prices were linked to the growth of the US corn ethanol industry [84]. The production of biofuels from microalgae has been extensively researched in recent decades. Microalgae can produce 58,700 litres of oil per hectare, which can, in turn, produce 121,104 litres of biodiesel per hectare, a seemingly promising departure from conventional fossil fuels [80].

The second generation of biofuels uses non-edible bio raw materials as raw materials for their production, which are relatively cheap and in abundance. The reviewed research shows that many researchers focus on forest biomass and wood by-products such as hardwood chips, sawdust, bark, as well as waste from gardens and parks such as branches, grass and leaves. Spent cereal and grain from distilleries and breweries can also be used as a raw material [83]. Thus, raw materials for the production of second-generation biofuels can be divided into five groups, namely industrial waste, agricultural waste, municipal solid waste, wood and forest waste and energy crops.

There are two main processes for obtaining liquid bioenergy from lignocellulosic raw material, namely thermochemical and biochemical conversion. Thermochemical conversion involves heating the feedstock in the presence of oxygen. The main advantage of this process is in the complete conversion of organic components. Pyrolysis/gasification creates a synthetic gas that regenerates long-chain carbon biofuel on the basis of Fischer-Tropsch technology. Coupled with advanced technologies such as calcium looping for carbon capture [85], this technology can provide a facile way of producing cleaner alternatives to 
traditional fossil fuels (e.g., synthetic methane). On the other hand, biochemical conversion relies on microorganisms and enzymes to convert cellulose and hemicellulose and reduce sugar. The basic steps for obtaining biofuels after this process are pretreatment of lignocellulosic raw material, biological/enzymatic hydrolysis, fermentation of reduced sugar and further processing of bioethanol [83].

\subsection{Anaerobic Digestion}

During anaerobic digestion (AD), biodegradable material is converted to $\mathrm{CH} 4, \mathrm{CO}_{2}$ and water by means of microbial fermentation in the absence of oxygen, leaving a partially stabilised wet organic mixture behind. AD can be a wet process used for materials with a moisture content of more than $85 \%$ or a dry process used for materials with a moisture content of less than $80 \%$. Anaerobic processes require less energy than aerobic ones and they generate much smaller amounts of biologically produced heat [79]. Figure 1 shows a schematic overview of the wet anaerobic digestion process with different potential uses of the produced biogas and digestate.

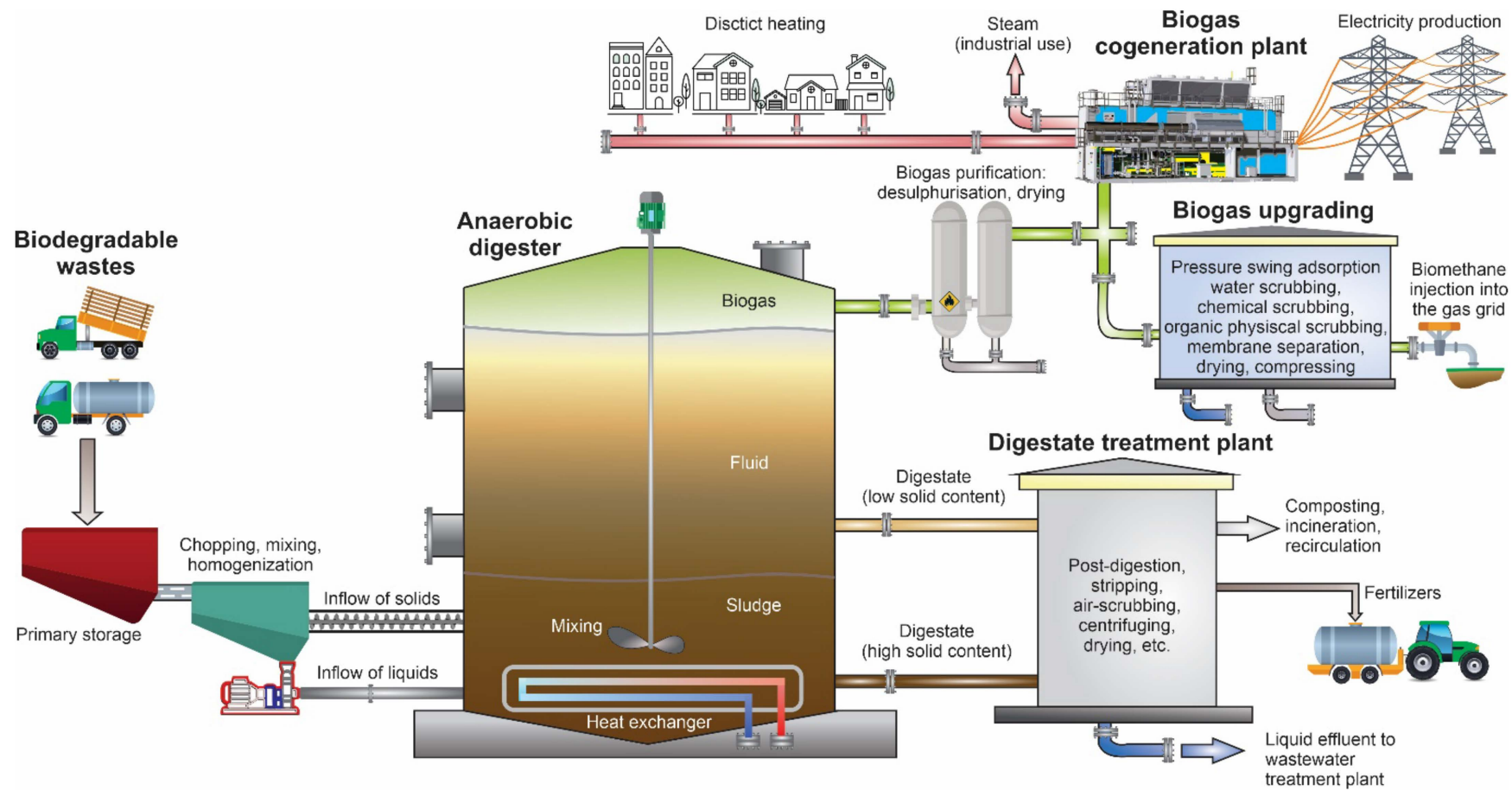

Figure 1. Schematic representation of the biogas production and utilisation.

During the anaerobic digestion process, biodegradable material is converted into combustible gas, commonly known as biogas, which predominantly consists of methane and carbon dioxide. Biogas can be burned on site to produce heat and/or electricity, it can be purified and used as a fuel, or it can be injected into the national gas grid if it meets the purity standards after upgrading. The remaining material is a wet solid or a liquid suspension of non-degradable materials, namely non-degradable organic matter, microbes, microbial residues and by-products of digestion. This partially stabilised wet mixture is known as the digestate, which can be further separated into solid and liquid fractions [86-88]. Theoretically, all substrates containing organic substances, such as carbohydrates, proteins and fats, can be used for anaerobic digestion. The conversion of organic matter into biogas can be expressed by Equation (1):

$$
\begin{gathered}
\mathrm{C}_{\mathrm{c}} \mathrm{H}_{\mathrm{h}} \mathrm{O}_{\mathrm{o}} \mathrm{N}_{\mathrm{n}} \mathrm{S}_{\mathrm{s}}+\mathrm{yH}_{2} \mathrm{O} \rightarrow \mathrm{xCH}_{4}+\mathrm{nNH}_{3}+\mathrm{sH}_{2} \mathrm{~S}+(\mathrm{c}-\mathrm{x}) \mathrm{CO}_{2} \\
\mathrm{x}=1 / 8(4 \mathrm{c}+\mathrm{h}-2 \mathrm{o}-3 \mathrm{n}+2 \mathrm{~s}) \& \mathrm{y}=1 / 4(4 \mathrm{c}-\mathrm{h}-2 \mathrm{o}+3 \mathrm{n}+3 \mathrm{~s})
\end{gathered}
$$


The reaction equations for the conversion of carbohydrates (Equation (2)), fats, (Equation (3)) and proteins (Equation (4)) into biogas are as follows:

$$
\begin{gathered}
\text { Carbohydrates: } \mathrm{C}_{6} \mathrm{H}_{12} \mathrm{O}_{6} \rightarrow 3 \mathrm{CH}_{4}+3 \mathrm{CO}_{2} \\
\text { Fats : } \mathrm{C}_{12} \mathrm{H}_{24} \mathrm{O}_{6}+3 \mathrm{H}_{2} \mathrm{O} \rightarrow 7.5 \mathrm{CH}_{4}+4.5 \mathrm{CO}_{2} \\
\text { Proteins : } \mathrm{C}_{13} \mathrm{H}_{25} \mathrm{O}_{7} \mathrm{~N}_{3} \mathrm{~S}+6 \mathrm{H}_{2} \mathrm{O} \rightarrow 6.5 \mathrm{CH}_{4}+6.5 \mathrm{CO}_{2}+3 \mathrm{NH}_{3}+\mathrm{H}_{2} \mathrm{~S}
\end{gathered}
$$

The share of produced carbon dioxide and methane depends on the composition of the input material and the degree of digestion. This approach helps improve waste management while it aims to meet the objectives of sustainable energy management. The use of waste biomass for biogas production generates a carbon neutral cycle. The process of anaerobic digestion is commonly found in many natural environments, such as swamps, and it is also present in the stomachs of ruminants. AD processes take about three to six weeks, depending on the ease and degree of conversion of the input material into biogas and the technology used. Pretreatment, co-digestion, bioaugmentation, biohythane, temperature, organic loading rate and reactor design are some of the ways to increase biogas yield [89]. It has also been shown that pretreatment methods, such as substrate preparation, mechanical solubilisation in combination with low-temperature heat treatment, affect biogas yield in AD processes with wastewater sludge because of a higher ability to dissolve sludge and consequent acceleration of anaerobic digestion [90]. In the case of waste containing a large amount of woody matter with a high lignin content, longer times are required to achieve the desired biogas production. Table 1 presents the advantages and disadvantages of waste

\begin{tabular}{|c|c|}
\hline Advantages & Disadvantages \\
\hline $\begin{array}{l}\text { - Energy production by producing high quality soil fertiliser } \\
\text { - } \quad \text { No need for additional power to turn the pile of waste for the } \\
\text { purpose of obtaining oxygen }\end{array}$ & $\begin{array}{l}\text { Less heat released, resulting in lower and less efficient destruction of } \\
\text { pathogens as in aerobic composting } \\
\text { Unsuitable for waste containing less organic matter }\end{array}$ \\
\hline - Closed system allows the use of all produced gas & Requirement for waste separation to improve decommissioning efficiency \\
\hline - Monitoring of greenhouse gas emissions & Pretreatment is essential \\
\hline - No unwanted odour, rodents and flies & Temperature sensitivity \\
\hline $\begin{array}{l}\text { - The modular construction of the plant and closed process } \\
\text { require smaller land (footprint) areas }\end{array}$ & Post-processing is required \\
\hline - Net positive environmental gains & $2-4$ months of start-up time \\
\hline - $\quad$ Possible implementation on a small scale & \\
\hline - Low power consumption & \\
\hline - Almost complete retention of nutrients in the fertiliser & \\
\hline - Possibility to store sludge for a longer period & \\
\hline - Construction costs are relatively low & \\
\hline - $\quad$ Low sludge production & \\
\hline - $\quad$ Low nutrient demand & \\
\hline - High organic removal & \\
\hline
\end{tabular}
recovery by means of anaerobic digestion process.

Table 1. Advantages and disadvantages of anaerobic digestion $[86,88]$.

The process of anaerobic digestion can be divided into four basic processes of biochemical reactions, namely:

- Hydrolysis;

- Acidogenesis;

- Acetogenesis;

- Methanogenesis. 
Hydrolysis is the first stage of digestion, where complex organic substances, such as carbohydrates, proteins and fats, are broken down into soluble organic molecules including sugars, amino acids, fatty acids and other components. In most cases, hydrolysis is the slowest part of the process due to volatile fatty acids and other toxic by-products. Hydrolysis can generally be accelerated by substrate pretreatment. The second phase is acidogenesis or fermentation, in which organic components from the hydrolysis phase are broken down into short-chain fatty acids, together with hydrogen, carbon dioxide and other by-products. The third stage of the anaerobic digestion process is acetogenesis, in which organic acids formed in the previous phase are transformed into acetic acid, hydrogen and carbon dioxide. The final stage is methanogenesis, where methane is produced by two groups of methanogens. One group breaks down acetic acid into methane and carbon dioxide, while the other group uses hydrogen and carbon dioxide to form methane [6,91-95].

Biogas yield can be improved through pretreatment of the raw material with processes such as chemolysis, pyrolysis and enzymolysis [14,25,37,88,96,97]. The use of aquatic plants for anaerobic digestion has two positive effects, namely the production of renewable energy and the reduction in waste. Some aquatic plants such as hyacinths, alligator weed, macroalgae and macroalgae that grow in ponds with water plants, in artificially built wetlands or eutrophic water, can reproduce rapidly and contain a high content of organic matter, which makes them an ideal raw material for anaerobic digestion [6]. Water hyacinth is known as one of the fastest growing aquatic weeds and has great potential for use as a feedstock for biogas production as well as being rich in nitrogen and other important nutrients and having a high content of fermentation material [98,99]. One of the promising species for energy use is Lemna minor (duckweed). Its positive properties include a short life cycle, high biological productivity and growth rate, survivability in various climatic zones of the globe and low demands regarding the quality of the water environment [100]. Research on anaerobic degradation of bioplastics is ongoing and, so far, the results have shown that the most common bioplastic polymers, poly(3-hydroxybutyrateco-3-hydroxyvalerate) (PHBV), can be degraded with energy production through AD [101].

Currently, the leading developed countries in the field of biogas production from waste are those with already developed anaerobic digestion technologies in widespread use, which have been developed and relied upon for decades. At the time of writing, the re are currently 302 AD biowaste plants in operation with Germany being the leader in terms of both the number of biogas plants and the amount of biogas produced with 92 AD biowaste plants in operation, followed by Italy, France and Austria. On a global scale, China has the largest number of plants for the production of biogas from waste worldwide [89]. Germany also has 1900 agricultural digesters out of the 2429 currently existing in Europe [89]. However, only around $50 \%$ of the mobilisable technical biomass potential of animal manure is used for energy purposes in Germany [102]. Overall, the technical potential of biogas in the EU is estimated to be between 151-246 billion $\mathrm{Nm}^{3}$ of biomethane from AD [89].

\subsection{Biogas Purification after Anaerobic Digestion}

With appropriate upgrades, biogas produced by the AD process can be used in many applications including systems with gas turbines and generators, internal combustion engines, production of heat for commercial and residential use and as a transport fuel at a very competitive price [89]. As mentioned previously, the two main components of biogas are methane $\mathrm{CH}_{4}$ and carbon dioxide $\mathrm{CO}_{2}$, which are accompanied by other impurities such as nitrogen $\mathrm{N}_{2}$, oxygen $\mathrm{O}_{2}$, hydrogen $\mathrm{H}_{2}$, hydrogen sulphide $\mathrm{H}_{2} \mathrm{~S}$ and ammonia $\mathrm{NH}_{3}$. The typical biogas volume composition is $50-75 \%$ methane, $25-45 \% \mathrm{CO}_{2}, 2-7 \%$ water vapor, less than $2 \%$ ammonia and less than $1 \%$ hydrogen sulphide [101]. This composition is generally suitable for less demanding applications such as generating heat and electricity at the place of production, where only minimal upgrading is required. However, for many other applications, biogas needs to be purified through removal of $\mathrm{CO}_{2}$ and other unwanted substances (especially sulphur compounds). Several typical impurities cause problems 
in various devices utilising (bio)gas. For example, high $\mathrm{O}_{2}$ concentration has explosive properties, while $\mathrm{H}_{2} \mathrm{~S}$ is corrosive. Moreover, chlorine is toxic and forms polyhalogenated dioxins [103], while siloxanes may lead to the formation of microcrystalline silica, which forms deposits and causes clogging problems. If biomethane is treated to a methane content of at least $60 \%$, the processing costs and the capital investment are lower. Biomethane with a methane content of more than $85 \%$ meets the minimum standards required by European countries and can generally be used as a fuel for vehicles [104]. However, its drawbacks include higher processing costs and a higher initial investment [105].

\subsection{Injection of Biomethane}

Because biomethane has a similar chemical composition to natural gas, its injection into the gas grid is not problematic. In some cases, the re is a need for additional equipment to enable injection into the transmission network, such as biogas upgrading and injection technology. The investment is economically feasible when the amount of locally produced biogas or biomethane exceeds the needs within the local distribution network and it is necessary to ensure the return flow to the transmission network. Another method of injecting biomethane into the transmission network is through a direct connection between the biogas plant and the network, including the necessary facilities for quality upgrading and injection.

About 30\% of the European Union Member States currently inject biomethane into their gas transmission network. These countries are Denmark, Germany, Italy, Spain, France, the Netherlands and Sweden. However, Belgium, Denmark, Italy, Slovenia, France, the Netherlands and Sweden envisage to invest and/or further adapt their National Development Programmes (NDP) to enable or increase future injection of biomethane into the transmission system. Through this, the percentage of countries with enabled biomethane injection could increase to $70 \%$ in the next years.

The responsibilities of biogas producers and transmission system operators (TSO) in eight European Union Member States is compared in Table 2. Furthermore, Table 3 shows whose task it is to provide a connection point for biomethane injection in the considered European Union Member States [106-108]. Here, "DSO" denotes the "distribution system operators".

Table 2. Responsibilities of biogas producers and transmission system operators.

\begin{tabular}{|c|c|c|}
\hline Country & Biogas Producer's Tasks & TSO's Tasks \\
\hline Austria & $\begin{array}{l}\text { Biogas producers are responsible for maintaining gas quality in } \\
\text { accordance with the requirements. }\end{array}$ & - \\
\hline $\begin{array}{l}\text { Czech } \\
\text { Republic }\end{array}$ & $\begin{array}{c}\text { Biogas producers are responsible for maintaining gas quality in } \\
\text { accordance with the requirements. }\end{array}$ & - \\
\hline Denmark & $\begin{array}{l}\text { The biogas producers operate the } \\
\text { upgrading plants that make biomethane from biogas. }\end{array}$ & $\begin{array}{l}\text { TSO operates the injection plants, including } \\
\text { gas compression. }\end{array}$ \\
\hline France & $\begin{array}{l}\text { The upgrading of biogas to biomethane is handled by the } \\
\text { biogas producers. }\end{array}$ & $\begin{array}{l}\text { The TSO is responsible for the operation and the } \\
\text { maintenance of the connection facilities and monitors the } \\
\text { quality of the biomethane before injection. }\end{array}$ \\
\hline Germany & $\begin{array}{l}\text { A biomethane plant owner who wants to inject into the network is } \\
\text { responsible for gas quality. }\end{array}$ & - \\
\hline Italy & $\begin{array}{c}\text { The owner of the biomethane plant is responsible for complying with } \\
\text { quality standards. }\end{array}$ & $\begin{array}{l}\text { TSO can interrupt injection if the quality does not meet } \\
\text { the requirements. }\end{array}$ \\
\hline Spain & $\begin{array}{c}\text { The biomethane producer is responsible for meeting gas quality } \\
\text { standards for injection. }\end{array}$ & - \\
\hline Sweden & The biomethane producer operates the gas quality upgrading facility. & TSO operates the injection facility. \\
\hline Netherlands & $\begin{array}{l}\text { Producer's tasks are odourisation, compliance with quality } \\
\text { specifications, pressure and ability for odourisation } \\
\text { according to standards. } \\
\text { Investment and operational costs are producer's tasks. }\end{array}$ & $\begin{array}{c}\text { Gas must be injected according to the requirements of } \\
\text { the DSO. } \\
\text { System operator's tasks are safety and technical } \\
\text { efficiency of the network. } \\
\text { TSO and DSOs are responsible for operating and } \\
\text { maintaining the gas network. }\end{array}$ \\
\hline
\end{tabular}


Table 3. Obligations for network operators to provide a connection point for biomethane injection [109-113].

\begin{tabular}{|c|c|c|}
\hline Country & Biogas Producer & DSO or TSO \\
\hline Denmark & - & $\begin{array}{l}\text { The obligation to provide a connection is for both the DSO and the } \\
\text { TSO, with the cost distribution and the determination of connection point } \\
\text { being regulated by the natural gas act. }\end{array}$ \\
\hline France & - & $\begin{array}{c}\text { Network operators are obliged to provide a biomethane connection point } \\
\text { (at DSO or TSO levels) in cases where the cost of this connection is below } \\
\text { a given threshold. }\end{array}$ \\
\hline Germany & & $\begin{array}{c}\text { The natural gas network operator is obliged to check whether it is possible to } \\
\text { inject biomethane. }\end{array}$ \\
\hline Hungary & The biomethane producer must finance the & The technical conditions for that are defined by the TSO. \\
\hline Italy & - & $\begin{array}{l}\text { A connection point must be provided by the TSO, as long as the connection } \\
\text { request meets the relevant technical and economic requirements. }\end{array}$ \\
\hline Poland & - & $\begin{array}{c}\text { A biomethane plant which is connected to the network must follow the rules } \\
\text { defined by the TSO. }\end{array}$ \\
\hline Portugal & - & $\begin{array}{l}\text { Operators shall provide information about capacity available for the injection } \\
\text { of biomethane into the network at different points, as well as provide a } \\
\text { connection point upon request by a producer. }\end{array}$ \\
\hline Netherlands & $\begin{array}{l}\text { Since DSO is not obligated to connect, } \\
\text { biogas producer must carry the costs. }\end{array}$ & DSO is not obligated to connect. \\
\hline
\end{tabular}

\section{Overview and Analysis of National Energy and Climate Plans for Selected EU Member States}

According to the EU's long-term decarbonisation strategy, the EU's annual consumption of renewable gas (biogas and biomethane) is projected to grow by 2050 to between 54 and 72 Mtoe, from around 17 Mtoe in 2017. We reviewed the Slovenian, Italian, Austrian, Swedish, Dutch and Danish national energy and climate plans (NECPs) and compared their future plans related to biogas, its upgrading to biomethane and biohydrogen and the biogas/biomethane injections into national gas networks. Table 4 shows the targets of individual countries for reducing greenhouse gas (GHG) emissions by 2030. The most ambitious goal of reductions by at least $40 \%$ was set by The Netherlands, followed by Denmark (39\%), while Slovenia and Sweden set the least ambitious goal of a $20 \%$ reduction in greenhouse gas emissions by 2030.

Table 4. Planned GHG emission reduction by 2030 [109-113].

\begin{tabular}{cc}
\hline Country & Planned GHG Emission Reduction by 2030 \\
\hline Austria & $36 \%$ \\
Denmark & $39 \%$ \\
Italy & $33 \%$ \\
Slovenia & $20 \%$ \\
Sweden & $20 \%$ \\
Netherlands & $>40 \%$ \\
\hline
\end{tabular}

Denmark has set itself the target of increasing the share of renewable energy sources (RES) in final use to $50 \%$ (Table 5), followed by Sweden and Austria, who are planning on increasing the share by $50 \%$ and $45-50 \%$, respectively. The Netherlands, Slovenia and Italy set less ambitious goals with a planned 27-35, 27 and 30\% share of RES in end use by 2030, respectively.

Table 5. Planned share of renewable energy sources in end use by 2030 [109-113].

\begin{tabular}{cc}
\hline Country & Planned Share of RES in End Use by 2030 \\
\hline Austria & $45-50 \%$ \\
Denmark & $55 \%$ \\
Italy & $30 \%$ \\
Slovenia & $27 \%$ \\
Sweden & $50 \%$ \\
Netherlands & $27-35 \%$ \\
\hline
\end{tabular}


A comparison of the objectives of individual countries regarding the introduction of RES in transport is made in Table 6. The largest increase in the share of RES in transport is again planned by Denmark, where plans are in place to stop the sales of new petrol and diesel cars by 2030. Denmark, Slovenia and Sweden are planning to introduce a sustainable focus on advanced biofuels in public transport as well.

Table 6. Renewable energy sources in transport [36,40-42,44].

\begin{tabular}{|c|c|}
\hline Country & RES in Transport \\
\hline Austria & Increasing the share of RES in transport to at least $14 \%$ with biofuels and increasing the share of e-mobility by 2030 \\
\hline \multirow{3}{*}{ Denmark } & A 55\% share of RES by 2030 \\
\hline & End of sales of new diesel and petrol cars by 2030 \\
\hline & A $21.6 \%$ share of RES in transport by 2030 \\
\hline \multirow[t]{3}{*}{ Italy } & A $6 \%$ reduction in GHG emissions by 2030 \\
\hline & Incentives for biomethane and other advanced fuels \\
\hline & A $21 \%$ share of RES in transport (share of biofuels in transport of at least 11\%) by 2030 \\
\hline \multirow[t]{2}{*}{ Slovenia } & Sustainable orientation towards the introduction of RES gases in CNG and LNG filling stations \\
\hline & $\begin{array}{l}\text { Sustainable focus on advanced biofuels and hydrogen, including change in the liquid fuel price regulation model } \\
\text { A } 27.2 \% \text { share of RES in transport by 2030; the additional target share is } 52 \% \text { by } 2040\end{array}$ \\
\hline \multirow{4}{*}{ Sweden } & A total $85 \%$ of public transport already used biofuels in 2018 \\
\hline & $\begin{array}{l}\text { Gas stations selling more than } 1500 \mathrm{~m}^{3} \text { of petrol or diesel annually are required to offer at least one type of } \\
\text { renewable source, by law }\end{array}$ \\
\hline & Share of RES in transport has increased to $9.5 \%$ from 2005 to 2018 \\
\hline & No energy taxes for the consumption of \\
\hline \multirow[t]{3}{*}{ Netherlands } & Promotion of electro-mobility, including hydrogen and fuel cell options \\
\hline & By 2030 all new cars will be emission free \\
\hline & Greater use of biofuels \\
\hline
\end{tabular}

Table 7 shows the comparison of waste-awareness-increasing projects set up by the specific EU Member States. Sweden and Austria plan to focus on less environmentally burdensome waste management by providing financial support for anaerobic digestion and biogas production. Slovenia is planning to focus on reducing waste generation, and the same applies to Sweden, which also intends to introduce a tax for depositing waste at landfill sites.

Table 7. Waste awareness projects [109-113].

\begin{tabular}{|c|c|}
\hline Country & Projects \\
\hline Austria & $\begin{array}{l}\text { Avoiding methane and carbon dioxide emissions from waste management, reducing biodegradable waste, reducing } \\
\text { single-use plastic products and increasing the proportion of recycled municipal waste and reducing methane } \\
\text { emissions from landfills. }\end{array}$ \\
\hline Denmark & $\begin{array}{l}\text { Improving the targets for organic food and strengthening initiatives against food waste, doubling the area under } \\
\text { organic farming, exporting organic food, consuming organic food and implementing initiatives to reduce food waste. }\end{array}$ \\
\hline Italy & $\begin{array}{l}\text { Between } 2000 \text { and 2017, 3.5 Mt of organic waste was treated, but the number of organic waste processing plants is still } \\
\text { increasing. An ambitious goal is to achieve } 60 \% \text { separate waste collection by } 2030 \text {. }\end{array}$ \\
\hline Slovenia & Promoting change in consumer patterns (pilot projects and tools to raise awareness of reuse, sharing, food waste reduction). \\
\hline Sweden & Prohibited disposal of organic waste, landfill taxes, financial support for biogas production and anaerobic digestion processes. \\
\hline & \\
\hline
\end{tabular}

In its NECP, Slovenia has an indicative goal to increase the share of gaseous fuels from renewable energy sources to $10 \%$ by 2030 . Today, biogas production accounts for only $1.8 \%$ of all gas consumption in Slovenia, and the plan assumes a mere $25 \%$ increase in biogas production compared to the existing capacity in 2020. Slovenia's NECP also includes environmental taxes, which represent the most important measure intended to reduce environmental pollution and are expected to result in more prudent waste management and will likely contribute to the reduction in GHG emissions [109,114]. 
Italy's NECP is committed to the development of power-to-gas technology (P2G; conversion of electricity to gaseous fuels) within the framework of smart grids, mainly due to its relatively large share of time-variable renewable energy sources. Biogas is mentioned in the Italian NECP only in relation to distributed small plants with up to a few $100 \mathrm{~kW}$ of installed power, and it is supposed to be produced by anaerobic digestion. Italy is therefore rather unambitious in the area of biogas production and use, as it aims to reduce carbon dioxide emissions mainly through renewable energy sources (RES) in the electricity sector and by the electrification of transport [110].

Austria aims to replace natural gas mainly with biogas, biomethane and hydrogen. By 2030, the country aims to increase energy production in biogas plants from the current $833 \mathrm{GWh}$ to $3611 \mathrm{GWh}$, which represents $6.6 \%$ of all gaseous fuels consumed in Austria in 2018. They propose to achieve this by increasing the share of anaerobic digestion of manure from the current $1 \%$ to $30 \%$ by 2030 . The country's priority in this area is maximisation of the share of biogas and the potential development of its upgrading to biomethane and biohydrogen and their injection into the national gas network. Austria, like Italy, wants to use biogas within the framework of a smart grid system to store surplus energy from renewable energy sources and to use surplus energy to generate electricity or heat or for transport. The Austrian targets regarding biogas, biomethane and biohydrogen are ambitious but realistic, and there is also potential for further increase in production growth, if required. However, the plan within the framework of smart grids, where only the existing possibilities for further development are listed, is less specific [111].

Sweden provides little data regarding the planned biogas production, stating only that the goal is to use 20 TWh of biogas in the energy balance sheet by 2030, which is $12.5 \%$ of all renewable sources in Sweden. In the future, the use of a FIT (feed-in tariff) is expected to be introduced to subsidise the production of biogas from manure and render possible its market competitiveness. The Swedish NECP is ambitious in this area but is probably rather unrealistic, given that biogas production capacity of Sweden is currently practically non-existent [112].

Denmark currently produces 1250 GWh of energy through biogas annually and has already developed capacities to upgrade biogas to biomethane, which is injected into the national low-pressure gas network at five injection stations, leading to biogas representing $15 \%$ of all gas consumed in the country in 2020. P2G technology is also being developed to store surplus electricity in the form of biomethane and hydrogen for later use in the energy and transport sectors. Considering the Danish situation, it can be concluded that their NECP is ambitious, but it should also be emphasised that Danish biogas technology is much more developed than the technology in most other European countries and only few of them plan on introducing such technology as their future goal [113].

In Table 8 , goals set by individual countries are analysed and the feasibility of achieving them by 2030 is assessed. The analysis was based on data obtained from national and energy climate plans and reasoning based on past scaling possibilities. The most ambitious goals have been set by Denmark, which, given Denmark's existing technology and inclusion of RES gases into the national power supply, also are the most realistic.

Table 8. Comparison of the common environmental policies of selected countries [109-113].

\begin{tabular}{|c|c|c|c|c|c|c|}
\hline & Slovenia & Italy & Austria & Sweden & Denmark & Netherlands \\
\hline $\begin{array}{l}\text { Share of biogas compared to natural } \\
\text { gas in } 2020\end{array}$ & $1.8 \%$ & $0 \%$ & $1.5 \%$ & $0 \%$ & $15 \%$ & - \\
\hline $\begin{array}{l}\text { The target of the share of biogas compared } \\
\text { to natural gas in } 2030\end{array}$ & $10 \%$ & $1 \%$ & $6.6 \%$ & No information. & $30 \%$ & - \\
\hline $\begin{array}{l}\text { Aims to upgrade biogas to } \\
\text { biomethane, hydrogen? }\end{array}$ & No & $\begin{array}{l}\text { Yes, hydrogen } \\
\text { non-existent. }\end{array}$ & $\begin{array}{c}\text { Yes, both } \\
\text { non-existent. }\end{array}$ & No & $\begin{array}{c}\text { Yes, both } \\
\text { already existing. }\end{array}$ & Yes \\
\hline $\begin{array}{l}\text { Aims to introduce smart } \\
\text { networks, power-to-gas? }\end{array}$ & No & Yes & Yes & Yes & Yes & Yes \\
\hline
\end{tabular}




\section{Analysis of Biogas Production from Waste around the World}

There are currently 50 million micro-digesters in the world, sufficient for family needs [115]. The total number of engineering biogas projects in the world is 132,000, with 17,783 located in Europe with an installed capacity of $10.5 \mathrm{GW}$. There are 700 plants for upgrading biogas to biomethane worldwide, 540 of which are in Europe [115,116]. It has been established that, currently, most of the existing waste management plants are intended for processing of waste into compost, which is only suitable for biodegradable waste, followed by public landfills and waste incinerations. For example, the data on the predominance of composting plants in Slovenia (Figure 2) are supplemented by the fact that, in 2018, most generated waste was processed by composting, while a larger amount of waste was processed by incineration or co-incineration than was deposited in public landfills [117-119].
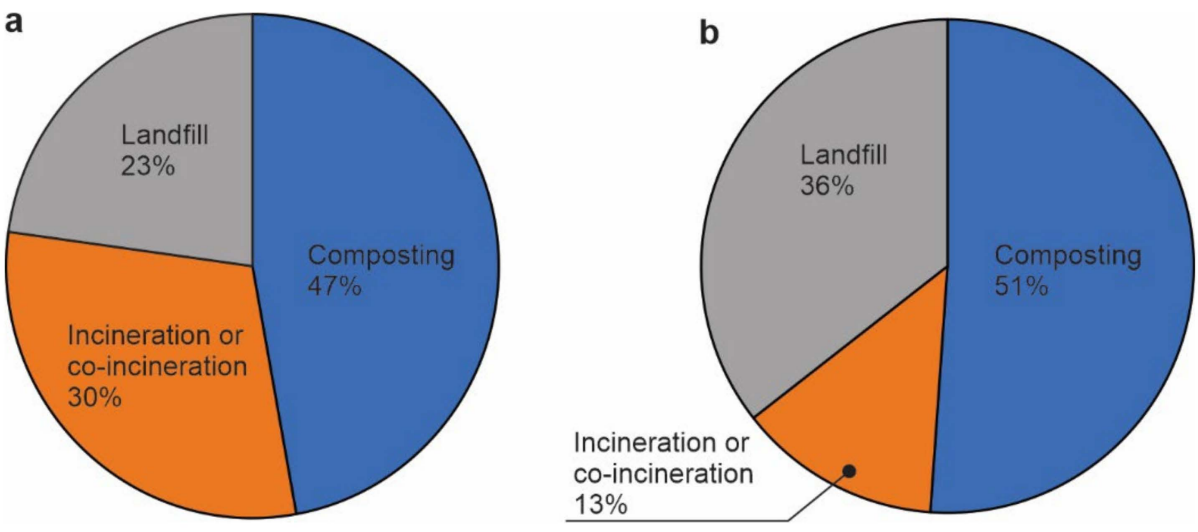

Figure 2. (a) Type of waste treatment in Slovenia in 2018 based on number of plants and (b) amount of recovered waste in landfills, by composting and incineration or co-incineration in Slovenia in 2018.

Overall, about 380 billion cubic metres of wastewater is generated around the world annually. Table 9 summarises some of the world wastewater treatment plants with additional anaerobic digestion technology. It should be noted that the small-capacity plants of less than $8000 \mathrm{PE}$ (population equivalent) are not considered in this comparison. For each plant, the following data were recorded: its location, the year of commissioning, the type of input material used for biogas production and the amount of biogas generated by a plant.

Table 9. List of selected wastewater treatment plants with anaerobic digestion worldwide with a capacity of more than 8000 PE.

\begin{tabular}{|c|c|c|c|c|c|c|}
\hline Location & Company & Year & Type of Waste & $\begin{array}{c}\text { Amount of Waste } \\
\text { Conversion }\end{array}$ & $\begin{array}{c}\text { Biogas } \\
\text { Production }\end{array}$ & Ref. \\
\hline Denmark, Hamburg & Hitachi Zosen INOVA & 2019 & SE & - & $930 \mathrm{Nm}^{3} / \mathrm{h}$ & {$[120]$} \\
\hline Italy, Bresso & - & 2019 & SE & - & $120 \mathrm{Nm}^{3} / \mathrm{h}$ & [121] \\
\hline Spain, Madrid & - & 2019 & SE & - & $50 \mathrm{Nm}^{3} / \mathrm{h}$ & [121] \\
\hline Netherlands, Den Hoorn & - & 2019 & SE & - & $720 \mathrm{Nm}^{3} / \mathrm{h}$ & [121] \\
\hline France, Marseille & - & 2019 & SE & - & $296 \mathrm{Nm}^{3} / \mathrm{h}$ & [121] \\
\hline France, Frejus & - & 2019 & SE & - & $107 \mathrm{Nm}^{3} / \mathrm{h}$ & [122] \\
\hline Ireland, Youghal & HoSt & 2018 & SE & $16,000 \mathrm{PE}$ & - & [123] \\
\hline Hungary, Zalaegerszeg & - & 2018 & SE & - & $50 \mathrm{Nm}^{3} / \mathrm{h}$ & [121] \\
\hline Estonia, Kunda & - & 2018 & SE & - & $550 \mathrm{Nm}^{3} / \mathrm{h}$ & [121] \\
\hline Germany, Bad Lippspringe & Ultrawaves & 2018 & SE & $30,000 \mathrm{PE}$ & - & [124] \\
\hline Germany, Delbruck & Ultrawaves & 2018 & SE & $54,000 \mathrm{PE}$ & - & [124] \\
\hline Germany, Hanau & Ultrawaves & 2018 & SE & $180,000 \mathrm{PE}$ & - & [124] \\
\hline Germany, Loddenbach & Ultrawaves & 2018 & SE & $45,000 \mathrm{PE}$ & - & [124] \\
\hline Germany, Nordhausen & Ultrawaves & 2018 & SE & $100,000 \mathrm{PE}$ & - & [124] \\
\hline Israel, Netanya & Ultrawaves & 2018 & SE & $260,000 \mathrm{PE}$ & - & [124] \\
\hline Germany, Magdeburg- Gerwisch & Ultrawaves & 2017 & SE & 430,000 PE & - & [124] \\
\hline
\end{tabular}


Table 9. Cont.

\begin{tabular}{|c|c|c|c|c|c|c|}
\hline Location & Company & Year & Type of Waste & $\begin{array}{l}\text { Amount of Waste } \\
\text { Conversion }\end{array}$ & $\begin{array}{c}\text { Biogas } \\
\text { Production }\end{array}$ & Ref. \\
\hline Switzerland, Uetendorf & - & 2017 & SE & - & $1000 \mathrm{Nm}^{3} / \mathrm{h}$ & \\
\hline Switzerland, Niedergösgen & Hitachi Zosen INOVA & 2017 & SE & - & $280 \mathrm{Nm}^{3} / \mathrm{h}$ & [120] \\
\hline Switzerland, Thun & Hitachi Zosen INOVA & 2017 & SE & - & $130 \mathrm{Nm}^{3} / \mathrm{h}$ & [120] \\
\hline Germany, Bad Kreuznach & Ultrawaves & 2017 & SE & $110,000 \mathrm{PE}$ & - & [124] \\
\hline Germany, Rheda- Wiedenbruck & Ultrawaves & 2017 & SE & $100,000 \mathrm{PE}$ & - & [124] \\
\hline Germany, Gera & Veolia & 2017 & SE & $200,000 \mathrm{PE}$ & - & [125] \\
\hline Germany, Burgebrach & Weltec BP & 2016 & SE & $13,000 \mathrm{PE}$ & - & [122] \\
\hline Germany, Heide & Ultrawaves & 2016 & SE & $40,000 \mathrm{PE}$ & - & [124] \\
\hline United Kingdom, Southport & Ultrawaves & 2016 & SE & $90,000 \mathrm{PE}$ & - & [124] \\
\hline Germany, Trier & Ultrawaves & 2015 & SE & $170,000 \mathrm{PE}$ & - & [124] \\
\hline Romania, Danutoni & Ultrawaves & 2015 & SE & $130,000 \mathrm{PE}$ & - & [124] \\
\hline Romania, Targu Secuiesc & Ultrawaves & 2015 & SE & $25,000 \mathrm{PE}$ & - & [124] \\
\hline Germany, Leinetal & Ultrawaves & 2015 & SE & $55,000 \mathrm{PE}$ & - & [124] \\
\hline Germany, Ratheim & Ultrawaves & 2014 & SE & $45,000 \mathrm{PE}$ & - & [124] \\
\hline UAE, Dubai & Ultrawaves & 2015 & SE & $1,100,000 \mathrm{PE}$ & - & [124] \\
\hline USA, Marengo & Ultrawaves & 2014 & SE & $10,000 \mathrm{PE}$ & - & [124] \\
\hline Germany, Ratzeburg & Ultrawaves & 2014 & SE & $34,000 \mathrm{PE}$ & - & [124] \\
\hline Switzerland, Zuchwil & Hitachi Zosen INOVA & 2014 & SE & - & $130 \mathrm{Nm}^{3} / \mathrm{h}$ & [120] \\
\hline Poland, Skarzysko & Ultrawaves & 2014 & SE & $65,000 \mathrm{PE}$ & - & [124] \\
\hline Netherlands, Assen & HoSt & 2013 & SE & - & $40 \mathrm{Nm}^{3} / \mathrm{h}$ & [123] \\
\hline USA, Akron & - & 2013 & SE & $330,000 \mathrm{PE}$ & - & [126] \\
\hline Brazil, Sabara & - & 2012 & SE & $1,944,000 \mathrm{PE}$ & - & [127] \\
\hline Hungary, Erd & Weltec BP & 2012 & SE & $33,000 \mathrm{PE}$ & - & [122] \\
\hline Finland, Espoo & - & 2012 & $\mathrm{SE}$ & - & $450 \mathrm{Nm}^{3} / \mathrm{h}$ & [121] \\
\hline Germany, Bargteheide & Ultrawaves & 2012 & SE & $34,500 \mathrm{PE}$ & - & [124] \\
\hline Denmark, Sondeborg & Ultrawaves & 2012 & SE & $80,000 \mathrm{PE}$ & - & [124] \\
\hline Spain, Tomelloso & Ultrawaves & 2012 & SE & $200,000 \mathrm{PE}$ & - & [124] \\
\hline France, Chebourg & Ultrawaves & 2011 & SE & $230,000 \mathrm{PE}$ & - & [124] \\
\hline France, St. Nazaire & Ultrawaves & 2011 & SE & $200,000 \mathrm{PE}$ & - & [124] \\
\hline Germany, Schleswig & Ultrawaves & 2011 & SE & $60,000 \mathrm{PE}$ & - & [124] \\
\hline Hungary, Zalaegerszeg & - & 2011 & SE & - & $42 \mathrm{Nm}^{3} / \mathrm{h}$ & [121] \\
\hline Germany, Hochst & - & 2011 & SE & - & $825 \mathrm{Nm}^{3} / \mathrm{h}$ & [121] \\
\hline Germany, Hamburg & - & 2011 & SE & - & $275 \mathrm{Nm}^{3} / \mathrm{h}$ & [121] \\
\hline Germany, Jockgrim & Ultrawaves & 2011 & SE & $21,000 \mathrm{PE}$ & - & [124] \\
\hline Ireland, Shanganagh & Ultrawaves & 2011 & SE & $186,000 \mathrm{PE}$ & - & [124] \\
\hline Poland, Bytom & Ultrawaves & 2011 & SE & $175,000 \mathrm{PE}$ & - & [124] \\
\hline Poland, Kielce & Ultrawaves & 2011 & SE & $350,000 \mathrm{PE}$ & - & [124] \\
\hline Chile, Santiago & - & 2011 & WW & $3,200,000 \mathrm{PE}$ & - & [121] \\
\hline Taiwan, Dan- Shui & Ultrawaves & 2011 & SE & $5,000,000 \mathrm{PE}$ & - & [124] \\
\hline China, Wuxi & Weltec Biopower & 2010 & $\mathrm{AF}, \mathrm{CR}, \mathrm{SE}$ & - & - & [122] \\
\hline Brazil, Arrudas & Ultrawaves & 2010 & SE & $2,000,000 \mathrm{PE}$ & - & [124] \\
\hline Romania, Iasi & Strabag & 2010 & SE & $6,264,000 \mathrm{PE}$ & - & [128] \\
\hline France, Lille Marquette & Strabag & 2010 & SE & - & - & [128] \\
\hline Germany, Kleinsteinbach & Ultrawaves & 2010 & SE & $40,000 \mathrm{PE}$ & - & [85] \\
\hline Austria, Asten/Linz & - & 2010 & SE & - & $450 \mathrm{~m}^{3} / \mathrm{h}$ & [126] \\
\hline Hungary, Szombathely & Ultrawaves & 2010 & SE & $80,000 \mathrm{PE}$ & - & [124] \\
\hline Poland, Glogow & Ultrawaves & 2010 & SE & $150,000 \mathrm{PE}$ & - & [124] \\
\hline Spain, Montornes & Ultrawaves & 2010 & SE & $100,000 \mathrm{PE}$ & - & [124] \\
\hline Germany, Ahrensburg & Ultrawaves & 2009 & SE & $50,000 \mathrm{PE}$ & - & [124] \\
\hline Netherlands, Veendam & HoSt & 2009 & SE & - & - & [123] \\
\hline United Kingdom, Mauri Hull & Waterleau & 2009 & IFW & - & $598 \mathrm{Nm}^{3} / \mathrm{h}$ & [123] \\
\hline Norway, Oslo & - & 2009 & SE & - & $375 \mathrm{Nm}^{3} / \mathrm{h}$ & [126] \\
\hline Spain, Tablada & Ultrawaves & 2009 & SE & 200,000 PE & - & [124] \\
\hline Spain, San Jeronimo & Ultrawaves & 2008 & SE & $275,000 \mathrm{PE}$ & - & [124] \\
\hline Spain, La Gavia & Ultrawaves & 2008 & SE & $268,000 \mathrm{PE}$ & - & [124] \\
\hline Poland, Slupsk & Ultrawaves & 2008 & $\mathrm{SE}$ & $250,000 \mathrm{PE}$ & - & [124] \\
\hline Poland, Babrowa-Gornicza & Ultrawaves & 2008 & SE & $200,000 \mathrm{PE}$ & - & [124] \\
\hline Hungary, Zalaergerszeg & Ultrawaves & 2008 & SE & $60,000 \mathrm{PE}$ & - & [124] \\
\hline Spain, Lorqui & Ultrawaves & 2007 & SE & $50,000 \mathrm{PE}$ & - & [124] \\
\hline Germany, Braunschweig & Veolia & 2007 & SE & $275,000 \mathrm{PE}$ & $1104 \mathrm{Nm}^{3} / \mathrm{h}$ & [125] \\
\hline Sweden, Goteborg & - & 2007 & SE & - & $1000 \mathrm{Nm}^{3} / \mathrm{h}$ & [126] \\
\hline Greece, Psyttalia & Ultrawaves & 2007 & SE & $5,000,000 \mathrm{PE}$ & - & [124] \\
\hline Germany, Bunde & Ultrawaves & 2007 & SE & $54,000 \mathrm{PE}$ & - & [124] \\
\hline Denmark, Marselisborg- Arhus & Ultrawaves & 2006 & SE & $220,000 \mathrm{PE}$ & - & [124] \\
\hline
\end{tabular}


Table 9. Cont.

\begin{tabular}{|c|c|c|c|c|c|c|}
\hline Location & Company & Year & Type of Waste & $\begin{array}{c}\text { Amount of Waste } \\
\text { Conversion }\end{array}$ & $\begin{array}{c}\text { Biogas } \\
\text { Production }\end{array}$ & Ref. \\
\hline Denmark, Frederikshavn & Ultrawaves & 2006 & SE & $130,000 \mathrm{PE}$ & - & [124] \\
\hline Netherlands, Nieuwgraaf & Ultrawaves & 2006 & SE & $440,000 \mathrm{PE}$ & - & [124] \\
\hline Netherlands, Willem- Annapolder & Ultrawaves & 2006 & SE & 55,000 PE & - & [124] \\
\hline Korea, Gang- Byeun & Ultrawaves & 2006 & SE & $1,500,000 \mathrm{PE}$ & - & [124] \\
\hline Germany, Meldorf & Ultrawaves & 2005 & SE & $72,000 \mathrm{PE}$ & - & [124] \\
\hline Germany, Bamberg & Ultrawaves & 2004 & SE & $230,000 \mathrm{PE}$ & - & [124] \\
\hline Germany, Stavenhagen & Strabag & 2003 & SE & - & - & [128] \\
\hline China, Haikou & Strabag & 2002 & SE & - & - & [128] \\
\hline Netherlands, Zeist & Ultrawaves & 2000 & SE & $75,000 \mathrm{PE}$ & - & [124] \\
\hline China, Yantai & Strabag & 2000 & SE & - & - & [128] \\
\hline Vietnam & - & 1999 & WW & - & - & [126] \\
\hline Hungary, North Pest & Veolia & - & SE & $200,000 \mathrm{PE}$ & - & [125] \\
\hline Germany, Bitterfeld & Waterleau & - & CIW & - & $433 \mathrm{Nm}^{3} / \mathrm{h}$ & [129] \\
\hline Spain (Heineken) & Waterleau & - & $\mathrm{BP}$ & - & $400 \mathrm{Nm}^{3} / \mathrm{h}$ & [129] \\
\hline France, Tereos & Waterleau & - & IFW & - & $1083 \mathrm{Nm}^{3} / \mathrm{h}$ & [129] \\
\hline Netherlands (Heineken) & Waterleau & - & $\mathrm{BP}$ & - & $163 \mathrm{Nm}^{3} / \mathrm{h}$ & [129] \\
\hline Belgium, (Claerebout Waesten) & Waterleau & - & IFW, AR, CR & - & $475 \mathrm{Nm}^{3} / \mathrm{h}$ & [129] \\
\hline Ghana (Diageo Kumasi) & Waterleau & - & $\mathrm{BP}$ & - & $133 \mathrm{Nm}^{3} / \mathrm{h}$ & [129] \\
\hline Togo (Castel) & Waterleau & - & $\mathrm{BP}$ & - & $108 \mathrm{Nm}^{3} / \mathrm{h}$ & [129] \\
\hline Morocco, Marrakech & Waterleau & - & SE & - & $750 \mathrm{Nm}^{3} / \mathrm{h}$ & [129] \\
\hline Morocco, Fez & Waterleau & - & SE & - & $1200 \mathrm{Nm}^{3} / \mathrm{h}$ & [129] \\
\hline India & - & - & WW & $8300 \mathrm{PE}$ & $0.5 \mathrm{Nm}^{3} / \mathrm{h}$ & [126] \\
\hline Ghana (Diageo Kumasi) & Waterleau & - & $\mathrm{BP}$ & - & $133 \mathrm{Nm}^{3} / \mathrm{h}$ & [129] \\
\hline
\end{tabular}

Legend: SE, sewage sludge; MSW, organic fractions of municipal solid waste; FW, food waste; GW, green waste BW, biological waste; SM, solid manure; LW, liquid waste; LS, liquid slurry; CR, crop residues; LO, leftovers; $A R$, agricultural residues; INBM, injection of biomethane into the network; HP, combination of heat and power; BFS, biomethane filling station; MT, membrane technologies; AS, amino-scrubbing; PSA, pressure swing adsorption; SS, source separated waste; WO, waste oil; WW, wastewater; E, electricity to the grid; AF, animal faeces T-heat; IW, industrial wastewater; CIW, wastes from chemical industry; IFW, wastes from food industry; BP, wastes from beverage production; $\mathrm{P}$, peat; $\mathrm{PE}$, population equivalent.

During the analysis of existing waste management plants around the world and in Europe, the focus was placed mainly on the quantity and type of waste processed by individual plants annually, the ir ability to upgrade biogas and the amount of methane produced (if the plant has the potential to upgrade biogas). Figure 3 shows the number of plants in the countries that produce the most biogas worldwide. Figure 3a shows the number of devices for anaerobic digestion, while Figure $3 b$ shows the number of wastewater sludge to biogas plants and biogas upgrading plants [115,116,120,122,124,128,130-140]. It should be noted that Figures 3 and 4 also consider plants with a capacity below 8000 PE.

a

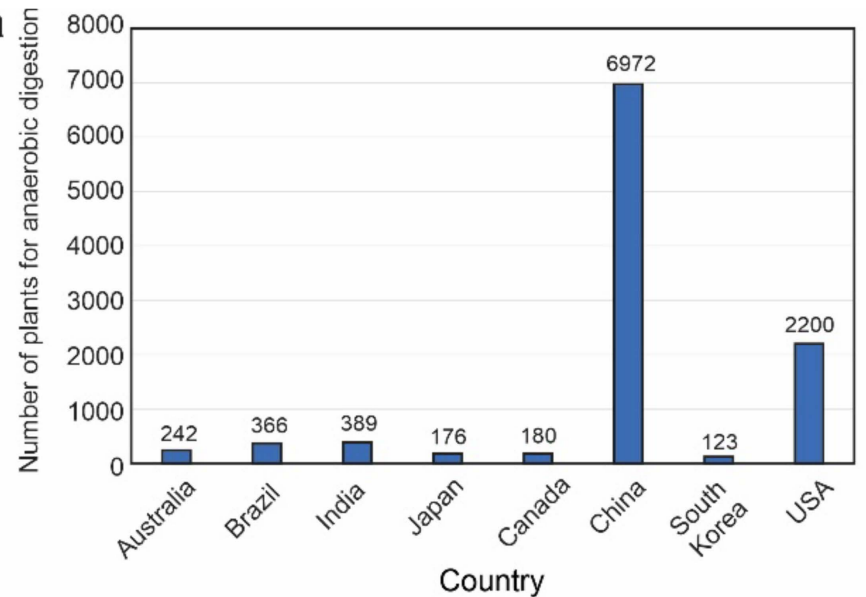

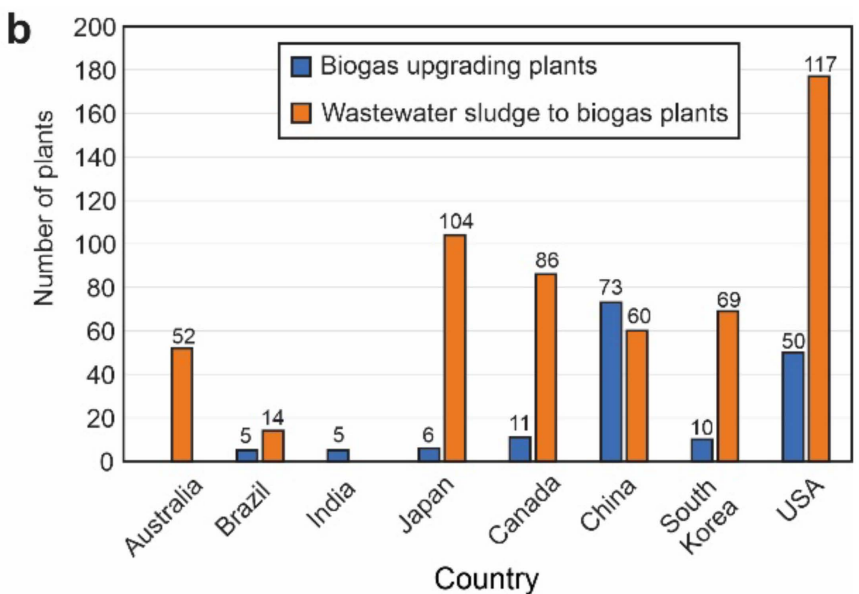

Figure 3. (a) The number of plants for anaerobic digestion for selected countries worldwide and (b) the number of plants for biogas upgrading and wastewater sludge to biogas plants for selected countries worldwide in 2019. 
a

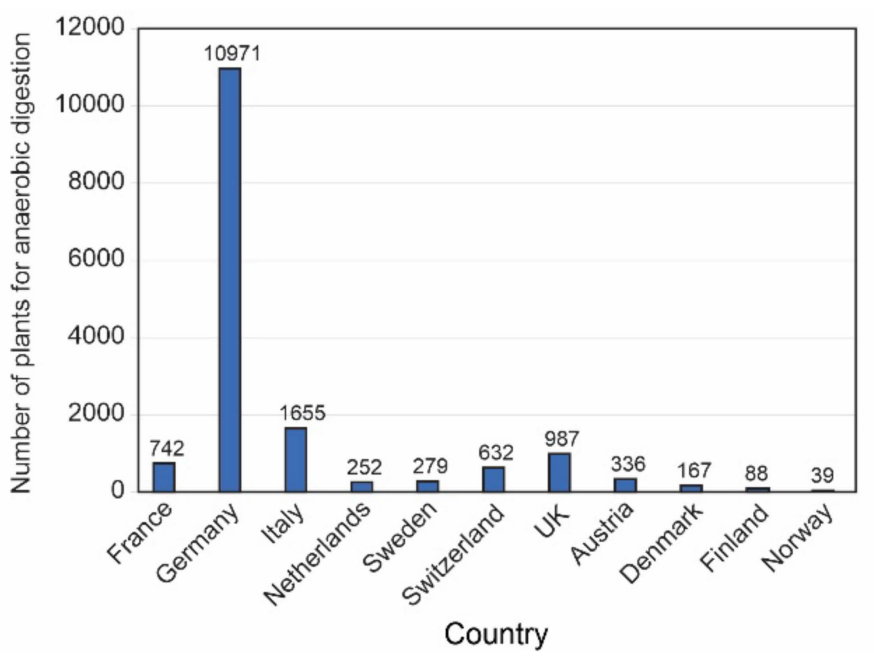

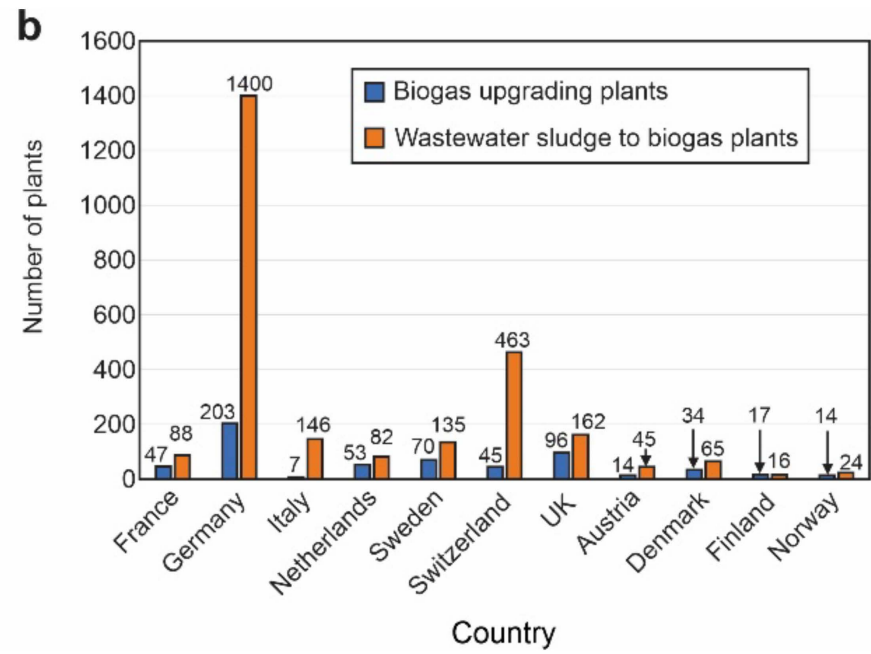

Figure 4. (a) The number of plants for anaerobic digestion in Europe and (b) the number of plants for biogas upgrading and wastewater sludge to biogas plants in Europe in 2019.

Figure 4 [141-147] shows the number of plants in the countries that produce the most biogas in Europe. Figure 4a shows the number of devices for anaerobic digestion, while Figure $4 \mathrm{~b}$ shows the number of wastewater sludge to biogas plants and biogas upgrading plants.

The number of new biogas plants increased significantly after 2005 [120,122,124,126,129,148], which is observable both on the global (Figure 5) and the European level (Figure 6).) Based on the analysed data, it can be concluded that the number of biogas plants is increasing significantly faster in Europe compared to the rest of the world (Figure 5). Based on data in Table 9, which are also presented in Figure 6b [120,122,124,126,129,148], the leading European country regarding the number of biogas plants is Germany, followed by France, Switzerland and The Netherlands (Figure 6).

a

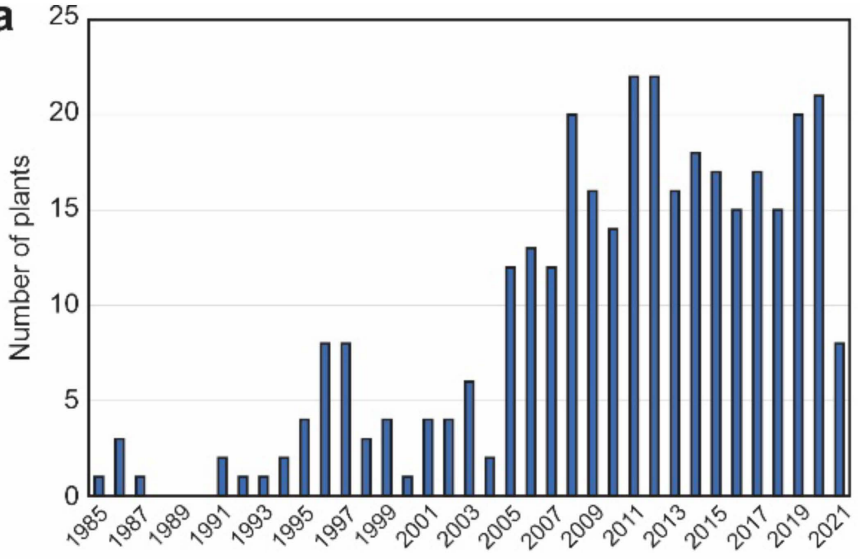

Year

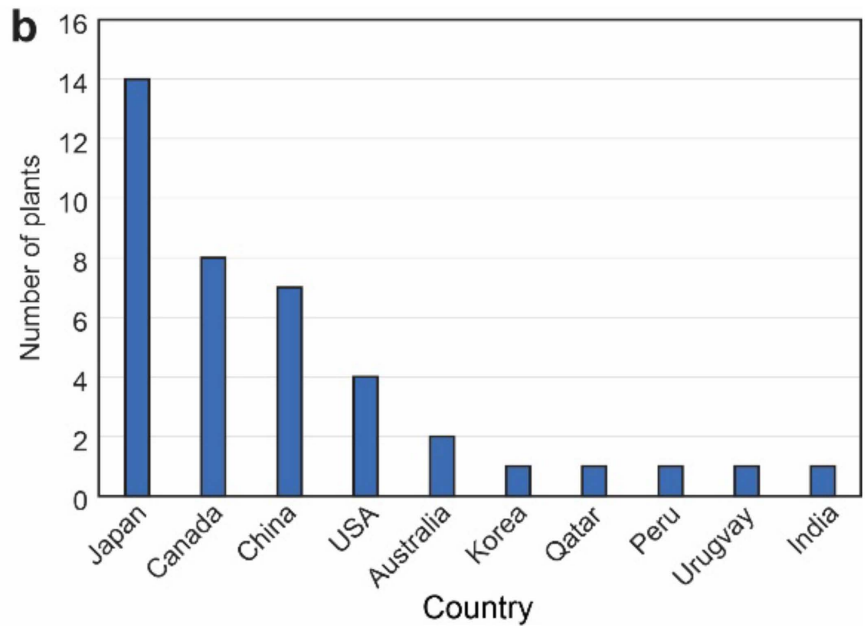

Figure 5. (a) The number of new waste-to-biogas plants in the period from 1998 to 2022 for selected countries around the world and (b) the number of waste-to-biogas plants for selected countries around the world.

Most biogas plants process waste such as biological waste, green waste, agricultural waste, food waste and other types of organic waste as shown in Figure 7a [120,122,124,126,129,148]. The analysed biogas plants in Europe were classified into 13 categories according to the amount of waste they process annually. It was found out that most plants process between 10,000 and 20,000 tonnes of waste per year as is evident from Figure 7b [120,122,124,126,129,148]. 

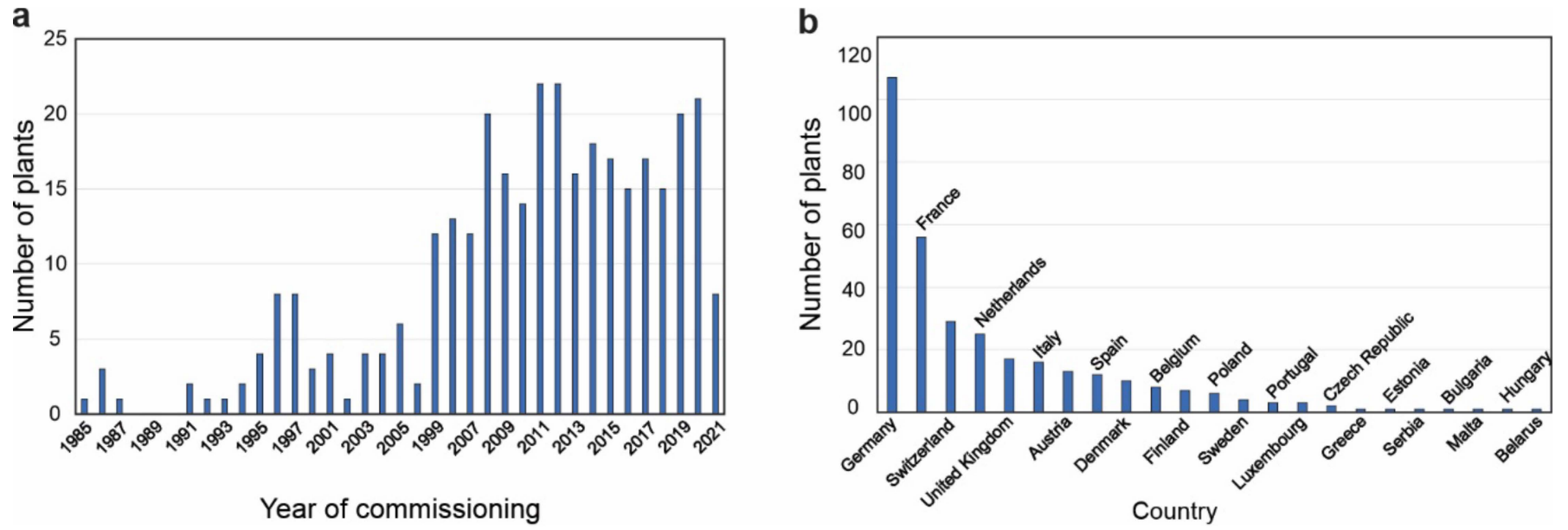

Figure 6. (a) The number of plants for anaerobic digestion of waste in the period from 1985 to 2021 at the European level for selected countries and (b) number of plants for anaerobic digestion of waste in the selected countries at European level.
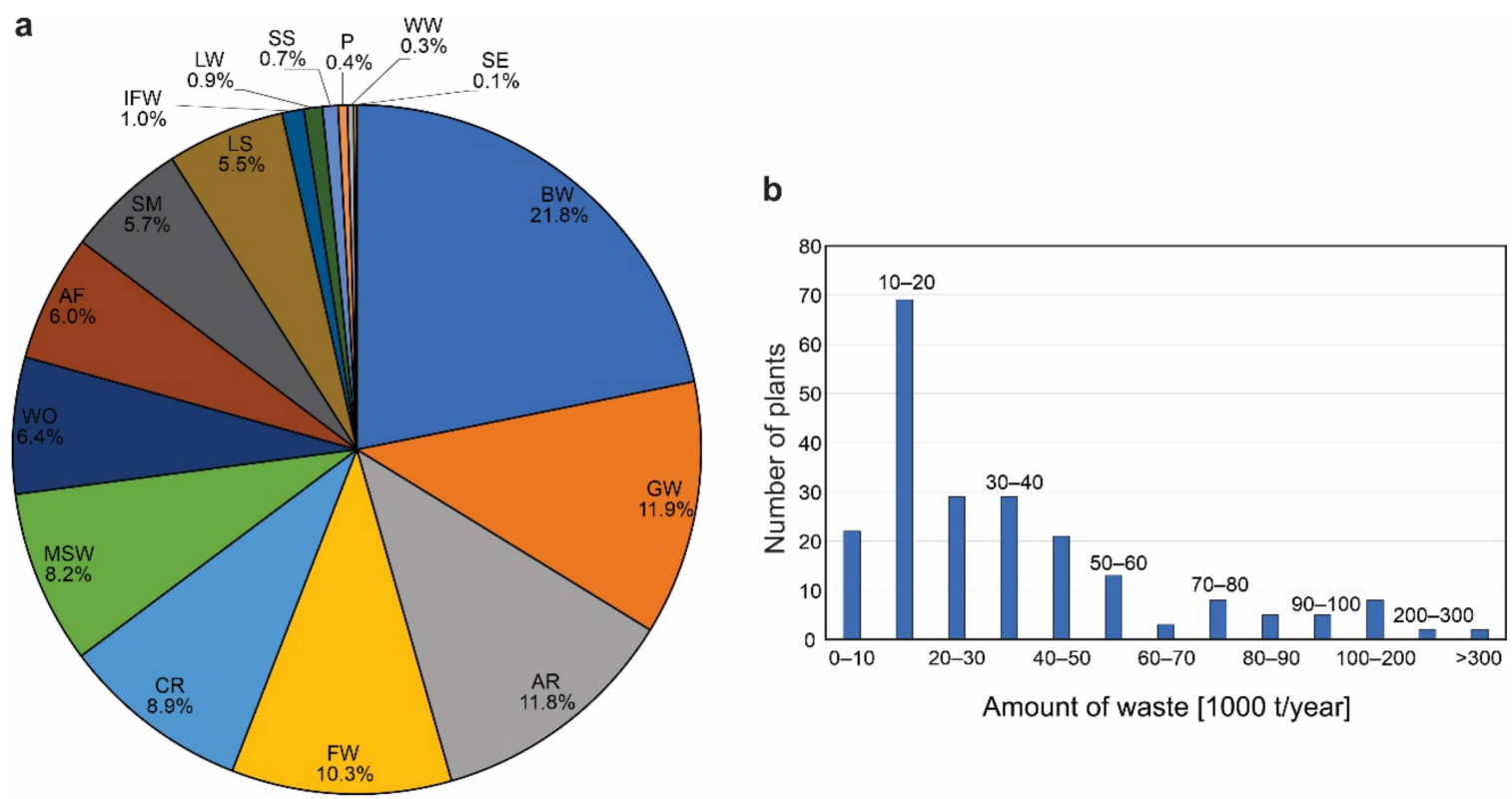

Figure 7. (a) Relative shares of different types of input waste for anaerobic digestion for selected biogas plants at European level and (b) waste-to-biogas plant capacities for selected biogas plants at European level in 2019.

Most installations only convert waste into biogas, but they do not allow biogas to be upgraded to biomethane for direct injection into the gas network. Out of a total of 383 plants analysed in this section, 134 plants have the possibility of upgrading biogas into biomethane (or at least have this option envisaged), while 86 plants do not have any biogas upgrade technology. For the remaining plants, no data could be found in the available literature.

\section{Conclusions}

Decarbonisation of society requires, among other aspects, intelligent waste management policies and integration of technologies for reusing waste materials to the highest possible extent. Waste-to-gas technology is one of the most environmentally friendly solutions for processing municipal and organic household waste, agricultural waste, livestock waste and biodegradable waste from any other sources. In this area, Germany is the leader 
in Europe both in terms of the number of biogas plants and the amount of biogas produced, followed by Italy, France and Austria, while the global leader is China with the largest number of plants for the production of biogas from waste. This work provides an overview of the current situation in Europe and worldwide in the field of waste processing into biogas, suitability of waste, the goals of selected Member States of the European Union on the path to decarbonisation as well as national energy and climate plans of selected countries related to waste-to-gas and development of actual projects to reach these goals.

The review shows that about $30 \%$ of the EU Member States currently inject biomethane into the gas transmission network (mainly Denmark, Germany, Italy, Spain, France, the Netherlands and Sweden). Many countries envisage to invest and/or further adapt their gas grid that would enable or increase future injection of biomethane into the gas transmission system. Through this, the percentage of countries with enabled biomethane injection could increase to $70 \%$ in the next years. Biogas producers are mostly responsible to comply with the rules regarding the quality of injected gas, while in Denmark, France and Sweden, the TSO is responsible for operating the biogas injection facility. The conditions and locations of possible injection points are determined by the TSO or the DSO, while the costs related to establishing a connection are either shared between the biogas producer and the TSO/DSO or solely on the side of the biogas producer.

According to the projections, the EU's annual consumption of renewable gas (biogas and biomethane) is projected to grow to between 54 and 72 Mtoe by 2050, from around 17 Mtoe in 2017. Regarding the national energy and climate plans by 2030, the most ambitious goal was set by Netherlands and Denmark, with a $>40$ and 39\% reduction in GHG emissions, respectively, while Slovenia and Sweden set the least ambitious goal of a $20 \%$ reduction. Projections of a significant increase in biofuel use and other renewable energy resources are also indicated for the transportation sector. Investments into the waste awareness projects are increasing throughout the EU. Overall, Slovenia aims to increase renewable gaseous fuels to $10 \%$ by 2030 (1.8\% in 2020), increase the biogas production by $25 \%$ compared to 2020 and increase or impose additional environmental taxes. Italy committed itself to the development of power-to-gas technology, while the biogas production is currently considered only for smaller plants (up to a few $100 \mathrm{~kW}$ ), which is less ambiguous compared to other EU countries. Austria aims to increase the share of anaerobic digestion of manure to increase energy production in biogas plants from 833 to $3611 \mathrm{GWh}$ by 2030. Biogas upgrading into biomethane and biohydrogen is also planned, along with their injection into the national gas network. Sweden set a goal of using 20 TWh of biogas by 2030 , which is $12.5 \%$ of all expected renewable energy sources consumed in Sweden. Since the current biogas production capacity in Sweden is low, significant investments will have to be made to reach their goal. Denmark already has a functioning infrastructure for biogas upgrading and gas injection, with the highest percentage of biogas usage (15\% of all gas consumed in the country in 2020 is biogas). Based on the data obtained from the national and energy climate plans and reasoning based on past scaling possibilities, the most ambitious goals among all EU countries have been set by Denmark, which, given Denmark's existing technology and inclusion of renewable gases into the national power supply, also have the most realistic possibility of being achieved.

There are currently 50 million micro-digesters in the world, 132,000 engineering biogas projects $(17,783$ in Europe, with an installed capacity of $10.5 \mathrm{GW})$ and 700 plants for upgrading biogas to biomethane (540 in Europe). Analysis showed that the number of biogas plants is increasing significantly faster in Europe compared to the rest of the world. Based on the capacity, it was found that most of the European plants process between 10,000 and 20,000 tonnes of waste annually. From 383 plants analysed, 134 plants have the possibility of upgrading biogas into biomethane (or at least have this option envisaged), while the rest do not have any biogas upgrade technology or the data were not available.

Most of the global waste still ends up in landfills (controlled and uncontrolled landfills), followed by composting (suitable only for biodegradable waste), followed by recycling and incineration. By also considering the wastewater sludge, the worldwide potential of 
partially converting waste into gas is enormous and still unexploited. Without intensified investments into biogas technology, accompanied by suitable legislation updates, it will not be able to reach the national and global decarbonisation goals in the future decade(s).

Author Contributions: Conceptualisation, M.Z. and M.M.; methodology, M.Z.; validation, M.M. and I.G.; investigation, M.Z., V.M. and F.C.; resources, F.C. and I.G.; data curation, V.M.; writingoriginal draft preparation, M.Z. and V.M.; writing—review and editing, M.Z., M.M., F.C. and I.G.; visualisation, M.Z. and V.M.; supervision, M.M., F.C. and I.G.; project administration, F.C.; funding acquisition, I.G. All authors have read and agreed to the published version of the manuscript.

Funding: This research was funded by the Slovenian Research Agency (Core Program No. P2-0223).

Data Availability Statement: The data presented in this study are available on request from the corresponding author.

Conflicts of Interest: The authors declare no conflict of interest.

\section{References}

1. Wilson, D.C.; Velis, C.A. Waste management-Still a global challenge in the 21st century: An evidence-based call for action. Waste Manag. Res. 2015, 33, 1049-1051. [CrossRef]

2. Kaza, S.; Yao, L.C.; Bhada-Tata, P.; Van Woerden, F. What a Waste 2.0: A Global Snapshot of Solid Waste Management to 2050; World Bank Publications: Washington, DC, USA, 2018; ISBN 1-4648-1347-7.

3. Dou, Z.; Toth, J.D. Global primary data on consumer food waste: Rate and characteristics-A review. Resour. Conserv. Recycl. 2020, 168, 105332. [CrossRef]

4. OECD. Stat, Stat Technology, 2020. Amount of Waste among OECD Databases. 2020. Available online: https:// data.oecd.org/ (accessed on 8 February 2020).

5. Dobers, G.M. Acceptance of biogas plants taking into account space and place. Energy Policy 2019, 135, 110987. [CrossRef]

6. Deng, L.; Liu, Y.; Wang, W. Biogas Technology, 1st ed.; Springer: Singapore, 2020.

7. Marchtinez, J.; Dabert, P.; Barrington, S.; Burton, C. Livestock waste treatment systems for environmental quality, food safety, and sustainability. Bioresour. Technol. 2009, 100, 5527-5536. [CrossRef] [PubMed]

8. Malinowski, M.; Wolny-Koładka, K. Microbiological and Energetic Assessment of the Effects of the Biodrying of Fuel Produced from Waste. Ecol. Chem. Eng. S 2017, 24, 551-564. [CrossRef]

9. Alfano, B.; Barretta, L.; Del Giudice, A.; De Vito, S.; Di Francia, G.; Esposito, E.; Formisano, F.; Massera, E.; Miglietta, M.L.; Polichetti, T. A Review of Low-Cost Particulate Matter Sensors from the Depvelopers' Perspectives. Sensors 2021, $20,6819$. [CrossRef]

10. Wolny-Koładka, K.; Malinowski, M.; Zdaniewicz, M. Energy-related and microbiological evaluation of the effects of bulking agents on the brewery hot trub biodrying. Food Bioprod. Process. 2021, 127, 398-407. [CrossRef]

11. Malinowski, M.; Famielec, S.; Wolny-Koładka, K.; Sikora, J.; Gliniak, M.; Baran, D.; Sobol, Z.; Salamon, J. Impact of digestate addition on the biostabilization of undersized fraction from municipal solid waste. Sci. Total Environ. 2021, 770, 145375. [CrossRef]

12. Gupta, P.; Singh, R.S.; Sachan, A.; Vidyarthi, A.S.; Gupta, A. Study on biogas production by anaerobic digestion of garden-waste. Fuel 2012, 95, 495-498. [CrossRef]

13. Perin, J.K.H.; Borth, P.L.B.; Torrecilhas, A.R.; da Cunha, L.S.; Kuroda, E.K.; Fernandes, F. Optimization of methane production parameters during anaerobic co-digestion of food waste and garden waste. J. Clean. Prod. 2020, 272, 123130. [CrossRef]

14. Hamer, G. Solid waste treatment and disposal: Effects on public health and environmental safety. Biotechnol. Adv. 2003, 22, 71-79. [CrossRef] [PubMed]

15. Lup, D.T.; Stroe, A.M.; Chezan, P.M.; Pica, E.M. The Importance of Waste Incineration. Stud. Univ. Babes-Bolyai Ambient. 2018, 63, 43-48. [CrossRef]

16. Vallero, D.A. Thermal Waste Treatment, 1st ed.; Elsevier Inc.: Amsterdam, the Netherlands, 2011.

17. Gómez-Brandón, M.; Podmirseg, S.M. Biological waste treatment. Waste Manag. Res. J. Sustain. Circ. Econ. 2013, 31, 773-774. [CrossRef] [PubMed]

18. Rada, E.C. Biological Treatment of Solid Waste, 1st ed.; Apple Academic Press: Waretown, NJ, USA, 2015.

19. Singh, A. Managing the uncertainty problems of municipal solid waste disposal. J. Environ. Manag. 2019, 240, 259-265. [CrossRef]

20. Rao, M.N.; Sultana, R.; Kota, S.H. Chapter 2-Municipal Solid Waste BT—Solid and Hazardous Waste Management, 1st ed.; Elsevier: Amsterdam, the Netherlands, 2017.

21. Salomone, R.; Saija, G.; Mondello, G.; Giannetto, A.; Fasulo, S.; Savastano, D. Environmental impact of food waste bioconversion by insects: Application of Life Cycle Assessment to process using Hermetia Illucens. J. Clean. Prod. 2017, 140, 890-905. [CrossRef]

22. Wolny-Koładka, K.; Zdaniewicz, M. Antibiotic Resistance of Escherichia coli Isolated from Processing of Brewery Waste with the Addition of Bulking Agents. Sustainability 2021, 13, 10174. [CrossRef] 
23. Read, Q.D.; Brown, S.; Cuéllar, A.D.; Finn, S.M.; Gephart, J.A.; Marchston, L.T.; Meyer, E.; Weitz, K.A.; Muth, M. Assessing the environmental impacts of halving food loss and waste along the food supply chain. Sci. Total Environ. 2020, 712, 136255. [CrossRef]

24. Cattaneo, A.; Federighi, G.; Vaz, S. The environmental impact of reducing food loss and waste: A critical assessment. Food Policy 2020, 98, 101890. [CrossRef]

25. García-Herrero, L.; De Menna, F.; Vittuari, M. Food waste at school. The environmental and cost impact of a canteen meal. Waste Manag. 2019, 100, 249-258. [CrossRef]

26. González-Morales, S.; Pérez-Labrada, F.; García-Enciso, E.L.; Leija-Marchtínez, P.; Medrano-Macías, J.; Dávila-Rangel, I.E.; Juárez-Maldonado, A.; Rivas-Marchtínez, E.N.; Benavides-Mendoza, A. Rheological and Microbiological Characteristics of Hops and Hot Trub Particles Formed during Beer Production. Molecules 2021, 22, 558. [CrossRef]

27. Zhukova, V.; Corte-Leon, P.; Blanco, J.M.; Ipatov, M.; Gonzalez, J.; Zhukov, A. The Application Potential of Hop Sediments from Beer Production for Composting. Chemosensors 2021, 9, 100. [CrossRef]

28. United Nations Framework Convention on Climate Change. The Paris Agreement. 2015. Available online: https://unfccc.int/ sites/default/files/english_paris_agreement.pdf (accessed on 10 January 2022).

29. UK Government. Un Climate Change Conference UK 2021 in Partnership with Italy, 2021. COP26: The Glasgow Climate Pact. Available online: https:/ / ukcop26.org/ (accessed on 10 January 2022).

30. Cudjoe, D.; Acquah, P.M. Environmental impact analysis of municipal solid waste incineration in African countries. Chemosphere 2021, 265, 129186. [CrossRef] [PubMed]

31. Istrate, I.-R.; Galvez-Marchtos, J.-L.; Dufour, J. The impact of incineration phase-out on municipal solid waste landfilling and life cycle environmental performance: Case study of Madrid, Spain. Sci. Total Environ. 2021, 755, 142537. [CrossRef] [PubMed]

32. Xiaoli, C.; Ziyang, L.; Shimaoka, T.; Nakayama, H.; Ying, Z.; Xiaoyan, C.; Komiya, T.; Ishizaki, T.; Youcai, Z. Characteristics of environmental factors and their effects on $\mathrm{CH}_{4}$ and $\mathrm{CO}_{2}$ emissions from a closed landfill: An ecological case study of Shanghai. Waste Manag. 2010, 30, 446-451. [CrossRef]

33. Adamcová, D.; Radziemska, M.; Ridošková, A.; Barton, S.; Pelcová, P.; Elbl, J.; Kynický, J.; Brtnický, M.; Vaverková, M.D. Environmental assessment of the effects of a municipal landfill on the content and distribution of heavy metals in Tanacetum vulgare L. Chemosphere 2017, 185, 1011-1018. [CrossRef] [PubMed]

34. Li, W.; Gu, K.; Yu, Q.; Sun, Y.; Wang, Y.; Xin, M.; Bian, R.; Wang, H.; Zhang, D. Leaching behavior and environmental risk assessment of toxic metals in municipal solid waste incineration fly ash exposed to mature landfill leachate environment. Waste Manag. 2021, 120, 68-75. [CrossRef] [PubMed]

35. Hoornweg, D.; Bhada-Tata, P.; Kennedy, C. Peak Waste: When Is It Likely to Occur? J. Ind. Ecol. 2014, 19, 117-128. [CrossRef]

36. Nagendran, R. Waste-A Handbook for Management, 2nd ed.; Elsevier: Amsterdam, the Netherlands, 2011.

37. Makisha, N.; Semenova, D. Production of biogas at wastewater treatment plants and its further application. In MATEC Web of Conferences; EDP Sciences: Ulis, France, 2018; Volume 144, p. 4016. [CrossRef]

38. Cinar, S.O.; Nsair, A.; Wieczorek, N.; Kuchta, K. Long-Term Assessment of Temperature Management in an Industrial Scale Biogas Plant. Sustainability 2022, 14, 612. [CrossRef]

39. Khademi, F.; Samaei, M.R.; Shahsavani, A.; Azizi, K.; Mohammadpour, A.; Derakhshan, Z.; Giannakis, S.; Rodriguez-Chueca, J.; Bilal, M. Investigation of the Presence Volatile Organic Compounds (BTEX) in the Ambient Air and Biogases Produced by a Shiraz Landfill in Southern Iran. Sustainability 2022, 14, 1040. [CrossRef]

40. Sauve, G.; Van Acker, K. The environmental impacts of municipal solid waste landfills in Europe: A life cycle assessment of proper reference cases to support decision making. J. Environ. Manag. 2020, 261, 110216. [CrossRef] [PubMed]

41. Randazzo, A.; Asensio-Ramos, M.; Melián, G.; Venturi, S.; Padrón, E.; Hernández, P.; Pérez, N.; Tassi, F. Volatile organic compounds (VOCs) in solid waste landfill cover soil: Chemical and isotopic composition vs. degradation processes. Sci. Total Environ. 2020, 726, 138326. [CrossRef] [PubMed]

42. Mattiello, A.; Chiodini, P.; Bianco, E.; Forgione, N.; Flammia, I.; Gallo, C.; Pizzuti, R.; Panico, S. Health effects associated with the disposal of solid waste in landfills and incinerators in populations living in surrounding areas: A systematic review. Int. J. Public Health 2013, 58, 725-735. [CrossRef]

43. Wolny-Koładka, K.; Malinowski, M.; Żukowski, W. Impact of Calcium Oxide on Hygienization and Self-Heating Prevention of Biologically Contaminated Polymer Materials. Materials 2020, 13, 4012. [CrossRef]

44. Flores, R.M.; Feratero, V.J.; Cobaria Soneja, S.K.; Rodelas Gonzales, R.P.A.; Burog, E.; Alvarez, C.J.B.; Bagus, D. A Case Study about the Improper Waste Disposal in Barangay Mojon Tampoy; A Research Paper Presented to the Faculty of De La Salle Lipa Senior High School; De La Salle Lipa: Lipa, Philippines, 2017.

45. Gopal, L.C.; Govindarajan, M.; Kavipriya, M.; Mahboob, S.; Al-Ghanim, K.A.; Virik, P.; Ahmed, Z.; Al-Mulahim, N.; Senthilkumaran, V.; Shankar, V. Optimization strategies for improved biogas production by recycling of waste through response surface methodology and artificial neural network: Sustainable energy perspective research. J. King Saud Univ. Sci. 2020, $33,101241$. [CrossRef]

46. Diamantis, V.; Eftaxias, A.; Stamatelatou, K.; Noutsopoulos, C.; Vlachokostas, C.; Aivasidis, A. Bioenergy in the era of circular economy: Anaerobic digestion technological solutions to produce biogas from lipid-rich wastes. Renew. Energy 2020, 168, 438-447. [CrossRef] 
47. Begum, S.; Anupoju, G.R.; Eshtiaghi, N. Anaerobic co-digestion of food waste and cardboard in different mixing ratios: Impact of ultrasound pre-treatment on soluble organic matter and biogas generation potential at varying food to inoculum ratios. Biochem. Eng. J. 2020, 166, 107853. [CrossRef]

48. Mateus, S.; Carvalheira, M.; Cassidy, J.; Freitas, E.; Oehmen, A.; Reis, M.A. Two-stage anaerobic digestion system treating different seasonal fruit pulp wastes: Impact on biogas and hydrogen production and total energy recovery potential. Biomass Bioenergy 2020, 141, 105694. [CrossRef]

49. Pozzo, A.D.; Guglielmi, D.; Antonioni, G.; Tugnoli, A. Sustainability analysis of dry treatment technologies for acid gas removal in waste-to-energy plants. J. Clean. Prod. 2017, 162, 1061-1074. [CrossRef]

50. Nevzorova, T.; Kutcherov, V. Barriers to the wider implementation of biogas as a source of energy: A state-of-the-art review. Energy Strat. Rev. 2019, 26, 100414. [CrossRef]

51. Gustafsson, M.; Anderberg, S. Dimensions and characteristics of biogas policies-Modelling the European policy landscape. Renew. Sustain. Energy Rev. 2020, 135, 110200. [CrossRef]

52. Brémond, U.; Bertrandias, A.; Steyer, J.-P.; Bernet, N.; Carrere, H. A vision of European biogas sector development towards 2030: Trends and challenges. J. Clean. Prod. 2020, 287, 125065. [CrossRef]

53. Lundmark, R.; Anderson, S.; Hjort, A.; Lönnqvist, T.; Ryding, S.-O.; Söderholm, P. Establishing local biogas transport systems: Policy incentives and actor networks in Swedish regions. Biomass Bioenergy 2021, 145, 105953. [CrossRef]

54. Wang, K.; Nakakubo, T. Comparative assessment of waste disposal systems and technologies with regard to greenhouse gas emissions: A case study of municipal solid waste treatment options in China. J. Clean. Prod. 2020, 260, 120827. [CrossRef]

55. Bi, S.; Westerholm, M.; Hu, W.; Mahdy, A.; Dong, T.; Sun, Y.; Qiao, W.; Dong, R. The metabolic performance and microbial communities of anaerobic digestion of chicken manure under stressed ammonia condition: A case study of a 10-year successful biogas plant. Renew. Energy 2020, 167, 644-651. [CrossRef]

56. Palma-Heredia, D.; Verdaguer, M.; Molinos-Senante, M.; Poch, M.; Cugueró-Escofet, M. Optimised blending for anaerobic co-digestion using ant colony approach: Besòs river basin case study. Renew. Energy 2020, 168, 141-150. [CrossRef]

57. Ali, M.M.; Ndongo, M.; Bilal, B.; Yetilmezsoy, K.; Youm, I.; Bahramian, M. Mapping of biogas production potential from livestock manures and slaughterhouse waste: A case study for African countries. J. Clean. Prod. 2020, 256, 120499. [CrossRef]

58. Chukwuma, E.C.; Okey-Onyesolu, F.C.; Ani, K.A.; Nwanna, E.C. GIS bio-waste assessment and suitability analysis for biogas power plant: A case study of Anambra state of Nigeria. Renew. Energy 2020, 163, 1182-1194. [CrossRef]

59. Dehkordi, S.M.M.N.; Jahromi, A.R.T.; Ferdowsi, A.; Shumal, M.; Dehnavi, A. Investigation of biogas production potential from mechanical separated municipal solid waste as an approach for developing countries (case study: Isfahan-Iran). Renew. Sustain. Energy Rev. 2019, 119, 109586. [CrossRef]

60. Stunzenas, E.; Kliopova, I. Optimizing municipal biodegradable waste management system to increase biogas output and nutrient recovery: A case study in Lithuania. Energy Procedia 2018, 147, 641-648. [CrossRef]

61. Mustafa, M.Y.; Calay, R.K.; Román, E. Biogas from Organic Waste - A Case Study. Procedia Eng. 2016, 146, 310-317. [CrossRef]

62. Bedoić, R.; Špehar, A.; Puljko, J.; Čuček, L.; Ćosić, B.; Pukšec, T.; Duić, N. Opportunities and challenges: Experimental and kinetic analysis of anaerobic co-digestion of food waste and rendering industry streams for biogas production. Renew. Sustain. Energy Rev. 2020, 130, 109951. [CrossRef]

63. Malik, S.N.; Madhu, K.; Mhaisalkar, V.A.; Vaidya, A.N.; Mudliar, S.N. Pretreatment of yard waste using advanced oxidation processes for enhanced biogas production. Biomass Bioenergy 2020, 142, 105780. [CrossRef]

64. Adami, L.; Schiavon, M.; Torretta, V.; Costa, L.; Rada, E.C. Evaluation of conventional and alternative anaerobic digestion technologies for applications to small and rural communities. Waste Manag. 2020, 118, 79-89. [CrossRef] [PubMed]

65. Li, Y.; Zhao, J.; Krooneman, J.; Euverink, G.J.W. Strategies to boost anaerobic digestion performance of cow manure: Laboratory achievements and their full-scale application potential. Sci. Total Environ. 2021, 755, 142940. [CrossRef] [PubMed]

66. Tseng, C.-H.; Hsu, Y.-C.; Chen, Y.-C. System dynamics modeling of waste management, greenhouse gas emissions, and environmental costs from convenience stores. J. Clean. Prod. 2019, 239, 118006. [CrossRef]

67. Sahoo, K.; Mani, S. Economic and environmental impacts of an integrated-state anaerobic digestion system to produce compressed natural gas from organic wastes and energy crops. Renew. Sustain. Energy Rev. 2019, 115, 109354. [CrossRef]

68. Lu, F.; Zhu, Y.; Pan, M.; Li, C.; Yin, J.; Huang, F. Thermodynamic, economic, and environmental analysis of new combined power and space cooling system for waste heat recovery in waste-to-energy plant. Energy Convers. Manag. 2020, 226, 113511. [CrossRef]

69. Yaman, C.; Anil, I.; Alagha, O. Potential for greenhouse gas reduction and energy recovery from MSW through different waste management technologies. J. Clean. Prod. 2020, 264, 121432. [CrossRef]

70. Chen, Y.-C. Evaluating greenhouse gas emissions and energy recovery from municipal and industrial solid waste using waste-toenergy technology. J. Clean. Prod. 2018, 192, 262-269. [CrossRef]

71. Yuan, X.; Fan, X.; Liang, J.; Liu, M.; Teng, Y.; Ma, Q.; Wang, Q.; Mu, R.; Zuo, J. Public Perception towards Waste-to-Energy as a Waste Management Strategy: A Case from Shandong, China. Int. J. Environ. Res. Public Health 2019, 16, 2997. [CrossRef] [PubMed]

72. Ren, X.; Che, Y.; Yang, K.; Tao, Y. Risk perception and public acceptance toward a highly protested Waste-to-Energy facility. Waste Manag. 2016, 48, 528-539. [CrossRef] [PubMed]

73. Zheng, J.; Yu, L.; Ma, G.; Mi, H.; Jiao, Y. Residents' acceptance towards waste-to-energy facilities: Formation, diffusion and policy implications. J. Clean. Prod. 2020, 287, 125560. [CrossRef] 
74. Zhang, S.; Li, Y.; Hao, Y.; Zhang, Y. Does public opinion affect air quality? Evidence based on the monthly data of 109 pre-fecturelevel cities in China. Energy Policy 2018, 116, 299-311. [CrossRef]

75. Pandyaswargo, A.H.; Gamaralalage, P.J.D.; Liu, C.; Knaus, M.; Onoda, H.; Mahichi, F.; Guo, Y. Challenges and An Implementation Framework for Sustainable Municipal Organic Waste Management Using Biogas Technology in Emerging Asian Countries. Sustainability 2019, 11, 6331. [CrossRef]

76. Republic of Slovenia, Government of the Republic of Slovenia. Waste Management Program and Waste Prevention Program of the Republic of Slovenia; Official Journal RS nr. 35402-1/2016/6; Government of the Republic of Slovenia: Ljubljana, Slovenia, 2016.

77. Tabasová, A.; Kropáč, J.; Kermes, V.; Nemet, A.; Stehlík, P. Waste-to-energy technologies: Impact on environment. Energy 2012, 44, 146-155. [CrossRef]

78. Brunner, P.H.; Rechberger, H. Waste to energy-Key element for sustainable waste management. Waste Manag. 2015, 37, 3-12. [CrossRef]

79. GOV UK; Department for Environment Food \& Rural Affairs DEFRA. Advanced Biological Treatment of Municipal Solid Waste; DEFRA: London, UK, 2013.

80. Suparmaniam, U.; Lam, M.K.; Uemura, Y.; Lim, J.W.; Lee, K.T.; Shuit, S.H. Insights into the microalgae cultivation technology and harvesting process for biofuel production: A review. Renew. Sustain. Energy Rev. 2019, 115, 109361. [CrossRef]

81. Mat Aron, N.S.; Khoo, K.S.; Chew, K.W.; Show, P.L.; Chen, W.; Nguyen, T.H.P. Sustainability of the four generations of biofuels-A review. Int. J. Energy Res. 2020, 44, 9266-9282. [CrossRef]

82. Alalwan, H.A.; Alminshid, A.; Aljaafari, H.A. Promising evolution of biofuel generations. Subject review. Renew. Energy Focus 2019, 28, 127-139. [CrossRef]

83. Ganguly, P.; Sarkhel, R.; Das, P. The Second- and Third-Generation Biofuel Technologies: Comparative Perspectives. In Sustainable Fuel Technologies Handbook; Elsevier: Amsterdam, the Netherlands, 2020; pp. 29-50. [CrossRef]

84. Thompson, P.B. The Agricultural Ethics of Biofuels: The Food vs. Fuel Debate. Agriculture 2012, 2, 339-358. [CrossRef]

85. Žalec, D.; Hanak, D.P.; Može, M.; Golobič, I. Process development and performance assessment of flexible calcium looping biomass gasification for production of renewable gas with adjustable composition. Int. J. Energy Res. 2021. [CrossRef]

86. Arriola, F.M.; Kumar, M.; Furumai, H.; Chaminda, T. Resilience, Response, and Risk in Water Systems, 1st ed.; Springer: Singapore, 2020.

87. Rhyner, C.R.; Schwartz, L.J.; Wenger, R.B.; Kohrell, M.G. Waste Management and Resource Recovery; CRC Press: Boca Raton, FL, USA, 1995.

88. Global Methane Initiative. Municipal Wastewater Methane: Reducing Emissions, Advancing Recovery and Use Oppor-Tunities. 2013. Available online: www.globalmethane.org (accessed on 2 February 2021).

89. Kamperidou, V.; Terzopoulou, P. Anaerobic Digestion of Lignocellulosic Waste Materials. Sustainability 2021, 13, 12810. [CrossRef]

90. Ahn, J.-Y.; Chang, S.W. Effects of Sludge Concentration and Disintegration/Solubilization Pretreatment Methods on Increasing Anaerobic Biodegradation Efficiency and Biogas Production. Sustainability 2021, 13, 12887. [CrossRef]

91. Sara Tanigawa Environmental and Energy Study Institute. Fact Sheet-Biogas: Converting Waste to Energy. Available online: https://www.eesi.org/papers/view/fact-sheet-biogasconverting-waste-to-energy/ (accessed on 9 September 2020).

92. Vögeli, Y.; Lohri, C.R.; Gallardo, A.; Diener, S.; Zurbrügg, C. Anaerobic Digestion of Biowaste in Developing Countries: Practical Information and Case Studies; Swiss Federal Institute of Aquatic Science and Technology: Dübendorf, Switzerland, 2014.

93. Kiran, E.U.; Stamatelatou, K.; Antonopoulou, G.L. Handbook of Biofuels Production: Processes and Technologies. Production of Biogas via Anaerobic Digestion, 2nd ed.; Elsevier Ltd.: Amsterdam, the Netherlands, 2016.

94. Hitachi Zosen Inova AG. References: Anaerobic Digestion. Available online: https://www.hz-inova.com/references/ (accessed on 10 January 2022).

95. La Fondation d'enterprise TotalEnergies, Planete Energies. How Does an Anaerobic Digester Work. Available online: https://www. planete-energies.com/en/medias/close/how-does-anaerobic-digester-work (accessed on 10 November 2020).

96. Berg, J.J.D. Van Effects of sewage sludge disposal. Land Degrad. Dev. 1993, 4, 407-413. [CrossRef]

97. Pham, M.; Pakrasi, A. Air Pollution Control Technologies, 1st ed.; Elsevier Inc.: Amsterdam, the Netherlands, 2017.

98. Patil, J.H.; Raj, M.A.; Muralidhara, P.L.; Desai, S.M.; Raju, G.K.M. Kinetics of Anaerobic Digestion of Water Hyacinth Using Poultry as Inoculum. Int. J. Environ. Sci. Dev. 2012, 3, 94-98. [CrossRef]

99. Hu, H.Y.Z. Anaerobic digestion of cattail by rumen cultures. Waste Manag. 2006, 26, 1222-1228. [CrossRef]

100. Chusov, A.; Maslikov, V.; Badenko, V.; Zhazhkov, V.; Molodtsov, D.; Pavlushkina, Y. Biogas Potential Assessment of the Composite Mixture from Duckweed Biomass. Sustainability 2022, 14, 351. [CrossRef]

101. Nachod, B.; Keller, E.; Hassanein, A.; Lansing, S. Assessment of Petroleum-Based Plastic and Bioplastics Degradation Using Anaerobic Digestion. Sustainability 2021, 13, 13295. [CrossRef]

102. Oehmichen, K.; Majer, S.; Thran, D. Biomethane from Manure, Agricultural Residues and Biowaste-GHG Mitigation Potential from Residue-Based Biomethane in the European Transport Sector. Sustainability 2021, 13, 14007. [CrossRef]

103. Awe, O.W.; Zhao, Y.; Nzihou, A.; Minh, D.P.; Lyczko, N. A Review of Biogas Utilisation, Purification and Upgrading Technologies. Waste Biomass Valorization 2017, 8, 267-283. [CrossRef]

104. Maile, O.I.; Muzenda, E.; Tesfagiorgis, H. Chemical Absorption of Carbon Dioxide in Biogas Purification. Procedia Manuf. 2017, 7, 639-646. [CrossRef]

105. Ohioline The Ohio State University. Biogas Cleaning and Upgrading Technologies. Available online: https://ohioline.osu.edu/ factsheet/AEX-653.1-14 (accessed on 10 November 2020). 
106. Ministry of Economic Affairs and Climate Policy. Integrated National Energy and Climate Plan, the Netherlands. Available online: https:/ / ec.europa.eu/energy/sites/ener/files/documents/nl_final_necp_main_en.pdf (accessed on 10 January 2022).

107. Sardi, K.; De Vita, A.; Capros, P.; European Commission, Directorate-General for Energy. The Role of Gas Dsos and Distribution Networks in the Context of the Energy Transition; European Commission: Brussels, Belgium, 2020.

108. International Energy Agency. The Netherlands 2020, Energy Policy Review. Available online: https://www.connaissancedesenergies. org/sites/default/files/pdf-actualites/The_Netherlands_2020_Energy_Policy_Review.pdf (accessed on 10 January 2022).

109. Republic of Slovenia, Government of the Republic Slovenia. Comprehensive National Energy and Climate Plan of The Republic of Slovenia. Available online: https:/ / www.energetika-portal.si/fileadmin/dokumenti/publikacije/nepn/dokumenti/nepn_5. 0_final_feb-2020.pdf (accessed on 22 March 2020).

110. Ministry of Economic Development; Ministry of the Environment and Protection of Natural Resources and the Sea; Ministry of Infrastructure and Transport. Integrated National Energy and Climate Plan of Italy. Available online: https://ec.europa.eu/ energy /sites/ener/files / documents /it_final_necp_main_en.pdf (accessed on 16 March 2020).

111. Federal Ministry Republic of Austria, Sustainability and Tourism. Integrated National Energy and Climate Plan for Austria. Available online: https:/ / ec.europa.eu/energy/sites/ener/files/documents/at_final_necp_main_en.pdf (accessed on 9 November 2020).

112. Regeringen, the Ministry of Infrastructure. Sweden's Integrated National Energy and Climate Plan. Available online: https: / / ec.europa.eu/energy/sites/ener/files/documents/se_final_necp_main_en.pdf (accessed on 22 March 2020).

113. Danish Ministry of Climate, Energy and Utilities. Denmark's Integrated National Energy and Climate Plan. Available online: https:/ / ec.europa.eu/energy/sites/ener/files/documents/dk_final_necp_main_en.pdf (accessed on 22 March 2020).

114. Slovenia, Ministry of Infrastructure of the Republic of Slovenia. Energy Portal. Available online: https://www.energetika-portal. si/statistika/ (accessed on 31 March 2020).

115. Zheng, L. What Could China Give to and Take from Other Countries in Terms of the Development of the Biogas Industry? Sustainability 2020, 12, 1490. [CrossRef]

116. Jain, S.; World Biogas Association. Global Potential of Biogas. Available online: https://www.worldbiogasassociation.org/wpcontent/uploads/2019/09/WBA-globalreport-56ppa4_digital-Sept-2019.pdf (accessed on 11 February 2021).

117. Republic of Slovenia, Ministry of the Environment and Spatial Planning, Slovenian Environment Agency. List of Landfills in the Republic of Slovenia and Their Status at 28 February 2020. 2020. Available online: https://www.gov.si/assets/organi-v-sestavi/ ARSO/Odpadki/Podatki/Upravljalci-odlagalisc.pdf/ (accessed on 2 February 2021).

118. Republic of Slovenia, Ministry of Public Administration. Records of Processors of Biodegradable Waste into Compost. 2019. Available online: https://www.gov.si/podrocja/okolje-in-prostor/okolje/ravnanje-z-odpadki/ (accessed on 2 February 2021).

119. Republic of Slovenia, Ministry of Public Administration. Records of Operators of Waste Incineration Plants and Waste CoIncineration Plants. 2019. Available online: https://podatki.gov.si/dataset/evidenca-upravljavcev-naprav-za-sosezig-alisezigalnic/resource/85a90137-e9a2-4d54-917b-b5af6c6f2a40 (accessed on 2 February 2021).

120. Hitachi Zosen INOVA AG. Reference Projects. 2021. Available online: https://www.hz-inova.com/media-downloads/ (accessed on 16 September 2020).

121. Global Methane Initiative. Successful Applications of Anaerobic Digestion from Across the World. 2013. Available online: https:/ / www.globalmethane.org/documents/gmibenefitsreport.pdf (accessed on 2 February 2021).

122. Weltec Biopower GMBH. Biogas Plants. 2016. Available online: https://www.weltec-biopower.com/en/references/referencesheets.html (accessed on 2 February 2021).

123. HOST Holding, B.V. Bio- Energy Installations. Biogas Plants, Renewable Energy from Anaerobic Digestion of Organic Waste. 2021. Available online: https:/ / www.host.nl/en/biogas-plants/ (accessed on 2 February 2021).

124. Ultrawaves. Installation List- Biogas Plants, Installations on Food Waste Biogas Plants and Farmland Biogas Plants. 2018. Available online: https:/ / ultrawaves.de/biogas-plants (accessed on 2 February 2021).

125. Veolia. Insights from Veolia Water Technologies, Innovative Water Solutions. 2022. Available online: https://www. veoliawatertechnologies.com/sites/g/files/dvc2476/files/document/2021/05/VeoliaWaterTech_WaveMagazine_2021 _Hubgrade.pdf (accessed on 2 February 2021).

126. European Biogas Association. European Biomethane Map. 2018. Available online: https://www.gie.eu/download/maps/2018 /GIE_BIO_2018_A0_1189x841.pdf (accessed on 2 February 2021).

127. Global Methane Initiative. Watewater Treatment Plants. 2013. Available online: https://www.globalmethane.org/documents/ ww_fs_eng.pdf (accessed on 2 February 2021).

128. Strabag Umwelttechnik GmbH. References Biogas Plants. 2016. Available online: https://www.strabag.com/databases/internet/ _public/files.nsf/aee78406ed324031c1257f720047de11/35f50bf5a234e070c125802c00429b5a/\$FILE/Refliste_Biogas_e.pdf (accessed on 2 February 2021).

129. Waterleau. Anaerobic Digestion: Energy Recovery from Bioeffluent, Sludge and Mixed Organic Waste. 2020. Available online: https:/ / www.waterleau.com/files / Anaerobic_digestion.pdf (accessed on 16 September 2020).

130. EPA 456-R-20-001, An Overview of Renewable Natural Gas from Biogas. 2020. Available online: https://www.epa.gov/sites / production/files/2020-07/documents/lmop_rng_document.pdf (accessed on 11 February 2021).

131. Government of India, Ministry of New and Renewable Energy. Bio Energy, Bio Mass Overview. 2020. Available online: https:/ / mnre.gov.in/bio-energy/current-status (accessed on 11 February 2021). 
132. Enea Consulting, Bioenergy Australia. Biogas Opportunities of Australia. 2019. Available online: https://www.enea-consulting. com/en/publication/biogas-opportunities-for-australia/ (accessed on 11 February 2021).

133. ABiogas, Associacao Brasileira do Biogas. Changing the World through Biogas. 2020. Available online: https://www. worldbiogasassociation.org/wp-content/uploads/2020/06/ABIOGÁS_Webinar-WBA.pdf (accessed on 11 February 2021).

134. Ministry of Foreign Affairs, Netherlands Enterprise Agency. Marchket Research: Biogas and Biomethane Current Stage and Opportunities for Dutch Companies in Brazil. 2019. Available online: https://www.rvo.nl/sites/default/files/2019/12/ Marchket_Study_Report_NBSO_EN_20191202.pdf (accessed on 11 February 2021).

135. Tonrangklang, P.; Therdyothin, A.; Preechawuttipong, I. Overview of Biogas Production Potential from Industry Sector to Produce Compressed Bio-Methane Gas in Thailand. Energy Procedia 2017, 138, 919-924. [CrossRef]

136. Federal Ministry for Economic Affairs and Energy. Thailand: Biogas Policy Update 12/2015. 2015. Available online: https:/ / www.thaigerman-cooperation.info/admin/uploads / publication/61c41993cd0d31b62f9e712b1bb96151en.pdf (accessed on 11 February 2021).

137. EnviTec Biogas AG. Biogas, Agricultural Biogas Plants. 2022. Available online: https://www.envitec-biogas.com/biogas (accessed on 10 November 2020).

138. World Biogas Association; Jain, S. Marchket Report: Japan. 2021. Available online: http://epower.pw/wp-content/themes/ epower/img/WBA-japan-4ppa4.pdf (accessed on 11 February 2021).

139. Canadian Biogas Association. Current Status and Future Potential of Biogas Production from Canada's Agriculture and AgriFood Sector. 2018. Available online: https://biogasassociation.ca/index.php/resources/canadian_agricultural_biogas_study (accessed on 11 February 2021).

140. EPA, United States Environmental Protection Agency. Projects \& Opportunities. AgSTAR Data and Trends. 2021. Available online: https: / / www.epa.gov/agstar/agstar-data-and-trends (accessed on 11 February 2021).

141. WBA, World Biogas Association. Anaerobic Digestion Marchket Report: The Netherlands. 2019. Available online: http://www worldbiogasassociation.org/wp-content/uploads/2018/07/The-Netherlands-International-Marchket-Report.pdf (accessed on 11 February 2021).

142. IEA Bioenergy, IEA Energy Technology Network. Task 37-Energy from Biogas, Biogas Country Overview (Country Reports). 2014. Available online: http:/ /task37.ieabioenergy.com/files/member-upload/Countryreportsummary2013.pdf (accessed on 11 February 2021).

143. IEA Bioenergy, Technology Collaboration Programme, University College Cork. Country Reports Summary 2017.2018. Available online: https:/ / www.ieabioenergy.com/blog/publications/iea-bioenergy-task-37-country-report-summaries-2017/ (accessed on 11 February 2021).

144. IEA Bioenergy; Theobald, O; French Agency for Environment and Energy Management. Task 37-France Country Report. 2015. Available online: http://task37.ieabioenergy.com/files/daten-redaktion/download/publications/country-reports/2015 /France_Country_Report_Berlin_10-2015.pdf (accessed on 11 February 2021).

145. Nordic Council of Ministers. BAT in Smaller Biogas Plants in the Nordic Countries. 2020. Available online: https://norden.divaportal.org/smash/get/diva2:1477056/FULLTEXT01.pdf (accessed on 11 February 2021).

146. Lybaek, R.; University of Roskilde, Institute of Human and Technology. The Danish Biogas Sector-Biogas Technology \& Policies \& Way Forward. 2020. Available online: https://www.maff.go.jp/primaff/koho/seminar/2016/attach/pdf/170111_01.pdf (accessed on 11 February 2021).

147. Kirchmeyr, F.; Austrian Compost; Biogas Association; Biosurf, Fueling Biomethane. Biogas Report from Austria: Possible Phase out of FIT and Perspectives How to Proceed. 2017. Available online: http:/ /www.biosurf.eu/wordpress/wp-content/uploads/ 2015/06/Trebon-VPBPS_2017_13_ARGE_Kirchmeyr.pdf (accessed on 11 February 2021).

148. BIOVOIMA. Biogas Plant- from Organic Waste and Side Streams to Income. 2019. Available online: https://biovoima.com/en/ solutions/biogas-plant (accessed on 10 November 2021). 